\title{
Teaching with Images among the Jews and Manichaeans of Late Antique Mesopotamia
}

\section{A Comparison of Doctrinal Content, Didactic Function, and Oral Context}

\author{
ZSUZSANNA GULÁCSI \\ Northern Arizona University, United States
}

\begin{abstract}
Although much has been written about the art of the famous synagogue at Dura-Europos, its rootedness in Mesopotamia has gone largely unexplored. This study looks south along the local trade routes to Iranian Babylonia and examines evidence available about the religious function of Durian Jewish and Sasanian Manichaean pictorial art as part of a shared regional development of techniques of instruction. It reveals that the distinctly different forms of pictorial art used by these two communities in mid-thirdcentury Mesopotamia are nevertheless comparable based on their didactic function. They both: (1) displayed a visual library of doctrinal subjects, that is, they captured, in pictorial form, a large sample of core tenets which were also recorded in the respective sacred texts of these religions; (2) fulfilled a primarily didactic function, that is, their pictorial genres (narrative scenes, didactic portraits, and diagrams in the Manichaean case) played a dominantly instructional role; and (3) effectively supplemented oral instruction, that is, the paintings were sermonized about and discussed in light of living interpretations. I argue that these correlations result not from direct influence between the two communities, but rather from a shared approach to what images can do for a religion. The Jewish and Manichaean paintings in question emerged simultaneously and in relative closeness to one another. While the Jewish archeological records of the painted synagogue are all but silent, various characteristics of the mid-third-century Manichaean paintings are noted in literary records, including what they portrayed and, most importantly for this study, the pedagogical reasons for how and why they were used. As evidenced by Iranian, Coptic, and Syriac textual sources from between the mid-third and the late fourth and early fifth centuries, the founding prophet of Manichaeism, Mani (active from 240 to 274/277 CE), not only wrote down his own teachings, but also created visual representations of them on a solely pictorial scroll—the Book of Pictures-that he and his highest-ranking elects used in the course of oral instructions while missionizing across greater West Asia and the East Mediterranean region.
\end{abstract}

KEYWORDS Dura-Europos, synagogue, Mani, Book of Pictures, Mesopotamia, religious art, murals, book paintings, function of art 


\section{Introduction $^{1}$}

The question of Mesopotamian rootedness has been on the minds of scholars of ancient Judaism who worked on the Dura synagogue. Its exploration, however, rarely has gone beyond the walls of the city. Recently, it was addressed by Lee Levine in his Visual Judaism in Late Antiquity. Levine stresses that the stunning pictorial program of the Dura synagogue that emerged with the renovation of the building in 244/45 CE owed its existence to its local cultural heritage and dedicates an entire chapter to it under the title "Eastern Religious Setting." Levine's focus stays within the city and on three places of worship-the synagogue, the church, and the Mithraeum—since these portrayed doctrinal teachings on their walls:

...each emphasizing something of the adherents' own historical or mythological heritage. [...] These religious communities—all relative newcomers to Dura, emerging under Roman rule-built or refurbished their buildings at the same time, each using a decorative scheme that highlights its particular Heilsgeschichte, its sacred icons or symbols [...], its god and his aretai. (Levine 2012, 78-79)

Skeptical of explanations speculating about conflict and/or competition among these communities, Levine is inclined to see some other "stimulus," stemming from the "unique configuration of religious cults at Dura," as the catalyst behind the decision to add narrative panels to the synagogue's meeting hall, the exploration of which is beyond the scope of his study.

The local stimulus alluded to by Levine was greater than Roman Dura and had a broader regional character that did not stop at the often changing and economically and culturally porous eastern border of the Roman Empire. Besides Semitic, Greek, and Roman elements, it included defining Iranian traits, which were more dominant in the southern, Sasanian-held regions of Mesopotamia. I argue that the exploration of the "eastern religious setting" does more justice to the Mesopotamian context of the Dura synagogue when it is extended-beyond the city's church and Mithraeum-further south along the local trade routes to include the artistic culture of another religion, Manichaeism, that emerged with a doctrinal and entirely didactic pictorial program roughly simultaneously (in the year $240 \mathrm{CE}$ ) and in relative spatial closeness to Dura (about a ten-day walking distance from it, Fig. 1) in and around the Sasanian capital city of (Greek) Ctesiphon / (Parthian) Tịsfūn (Perkins 1973, 3-4).

Numerous reasons call for bringing third-century Manichaean art to bear on understanding the Jewish murals at Dura in their Mesopotamian context. In addition to writing down his own teaching, the founding prophet of the Manichaean religion, Mani (active from 240 to 274 or 277 CE), authored visual representations of them in a solely pictorial scroll-the Book of Pictures. The images of this scroll depicted Mani's doctrine about soteriology, prophetology, theology, cosmology, and eschatology in diagrams, narrative scenes, and didactic portraits of deities. Fitting the itinerant lifestyle of Mani and his missionary elects, this portable work of art and its contemporaneous copies were used in the course of oral instructions while proselytizing across Mesopotamia, the Eastern Mediterranean, West Central Asia, and northern India. At the same time, the Jews at Dura renovated their synagogue, apparently in 244/245CE. They added a pictorial program to their meeting hall by covering its four walls with narrative panels, encircling the community in three dense registers of figural art. Independently of one

1 A condensed version of this study was invited for publication in a thematic volume of the Journal of Ancient Judaism under the title "Visual Catechism in Third-century Mesopotamia: Reassessing the Pictorial Program of the Dura-Europos Synagogue in light of Mani's Book of Pictures" (Gulácsi 2018). 


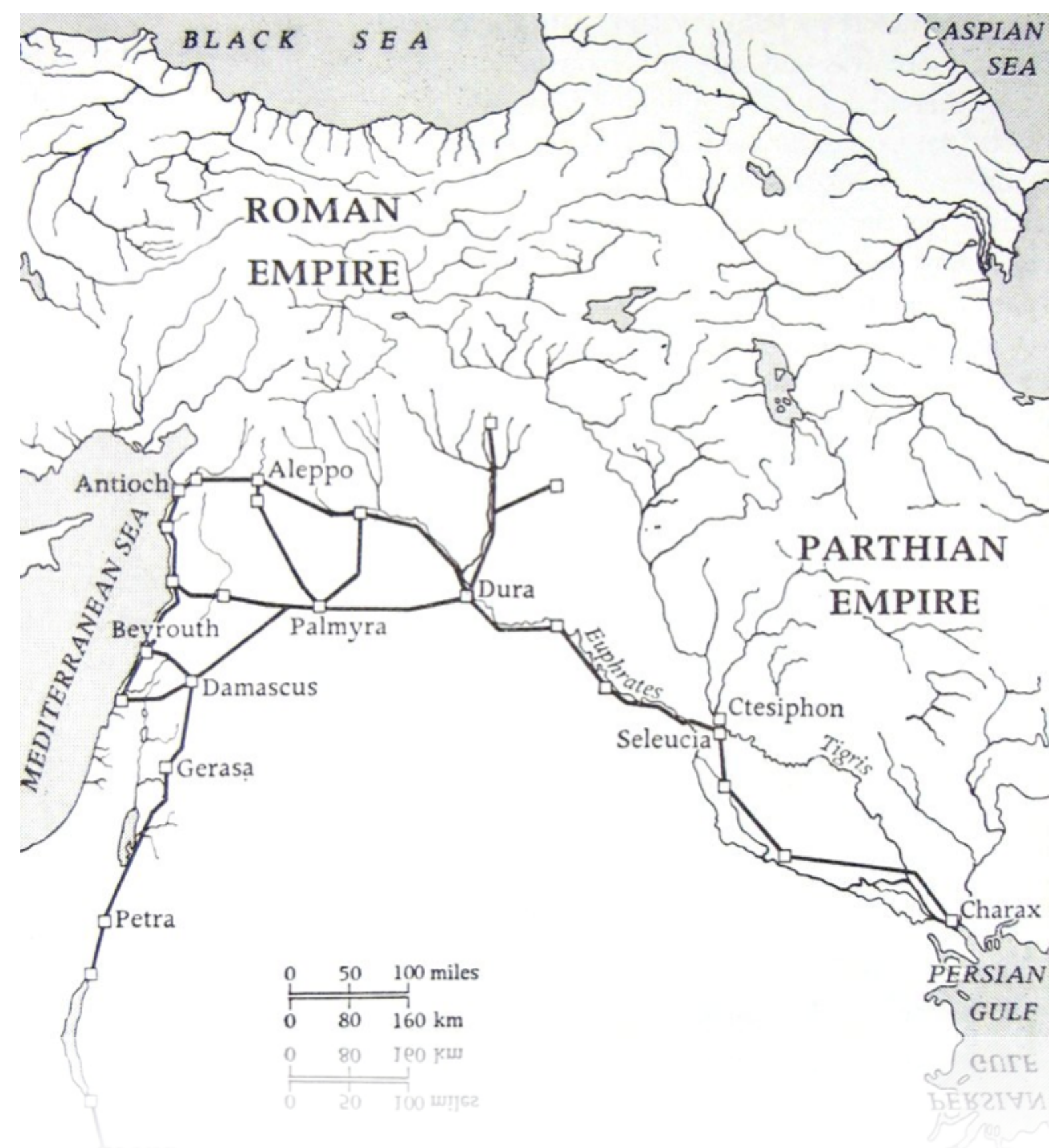

Figure 1 Map showing the location of (Aram.) Dura / (Gr.) Europos and (Gr.) Ctesiphon / (Part.) Ṭisfūn on the trade routes of Mesopotamia, after Perkins (1973, 3). 
another, the leaders of both communities proselytized and invested heavily into making art. This is extensively documented in late ancient sources about the Manichaeans. In the case of the synagogue, it is frequently overlooked that one of the three leaders of this community is explicitly called "the proselyte," implying that the community not only welcomed proselytes but even accepted them in high positions. ${ }^{2}$ Along with the next generation, the new converts needed instruction, for which images supplied one tool within regional practice. In both cases, the art in question had associations with the divine and its worship, but was not intended to be the focus of devotion. Moreover, it fulfilled a 'decorative' function only in a sense that it was pictorial and created by skilled artisans in an aesthetically pleasing manner. Its presence undoubtedly enhanced, that is, 'made special,' the religious experience. Extensive content and figures identified by labels as we find in the Dura synagogue, however, are not needed for decoration. If this art served primarily neither a devotional nor a decorative function, what function did it serve? The contemporaneous and nearby example of Manichaean practice offers an alternative function as a logical point of comparison-images employed as a tool of instruction. At minimum, visual representations of doctrine can indirectly reinforce religious teaching. When directly engaged in the course of a sermon, a visual representation can aid comprehension and facilitate the mastery of religious knowledge-and the Duran Jews may have recognized this as readily as their Manichaean neighbors as part of a regional development of techniques of religious instruction.

While the murals of the Dura synagogue and Mani's Book of Pictures clearly overlap chronologically, geographically, and arguably in function, their distinctions are still considerable. The former retains only about fifteen identifiable narrative scenes from what originally was a program of about sixty ${ }^{3}$ framed and large-scale depictions, displayed permanently on the walls within the main hall of a community building, engaged possibly on a weekly basis in front of a large group of people. The latter is attested in late ancient texts as a portable work of art and its copies, containing an estimated 20-30 framed images, painted on a scale to fit onto the surface of a horizontal parchment handscroll that was accessed one or two images at a time in an itinerant setting, in front of a smaller group of people. Such distinctions of survival, scale, and conditions of use, however, do not detract from evidence of a similar function.

The goal of this study is to demonstrate that correlations between third-century Duran Jewish and Manichaean art go beyond surface similarities in three regards: (1) They both displayed a visual library of doctrinal subjects, that is, they capture, in pictorial form, a large sample of core tenets that were also recorded, independently from the art, in the sacred texts of their respective religions; (2) they both fulfilled a primarily didactic function, that is, their pictorial genres (narrative scenes, didactic portraits, and emblems in the Jewish case; and narrative scenes, didactic portraits, and diagrams in the Manichaean case) had a dominantly instructional role; and, (3) they both were utilized in the course of oral instruction, that is, the paintings were referenced during sermons and were the subjects of living interpretations.

The comparative analyses of these points requires working with two different types of sources (archaeological and textual) about the function of art produced and used during the third century by the two distinct communities. While Mani's collection of paintings from

2 Recorded on ceiling Tiles A-B, the Aramaic dedicatory inscription of the synagogue mentions "those who stood in charge of this work," including "the proselyte" a person whose name does not survive, see Kraeling (1956, 263).

3 Only one-quarter of the narrative program survives in a condition for its subjects to be identifiable, which explains why many books of the Hebrew Bible (Genesis, large parts of Exodus, and later books) are not found among the panels today. For further discussion, see note 46 below. 
ancient Mesopotamia does not survive, a significant body of textual references written between the mid-third and late fifth centuries in primary Manichaean and secondary polemical accounts do survive, discussing what the paintings showed, how they were used, and why they were needed. These texts were collected for the first time in a recent monograph that accessed their evidence on the pictorial content and the religious function of Mani's Book of Pictures (Gulácsi 2015). ${ }^{4}$ In contrast, no textual sources discuss the Dura synagogue, its paintings, and their use. Beside a prayer (on three fragments of a parchment scroll) and the various inscriptions (on the ceiling tiles and murals of the synagogue), the Duran Jews and their visitors did not leave behind textual records. It is the physical remains of their synagogue-one of the best-studied and best-preserved archeological sites of late antique Mesopotamia-that provides rich data on subject matter and architectural context suited for studying the religious function of art in mid third-century Mesopotamia (Fig. 2). Comparative Manichaean data allows us to see the Jewish paintings at Dura in a new way-as a visual tool for oral instruction in late ancient Mesopotamia. These two contemporary cases vividly document that the display of doctrinal images and the practice of using them for instruction was integral to Mesopotamian religious art during the middle of the third century.

The temporal and geo-cultural relatedness of the synagogue's murals at Dura and Mani's Book of Pictures justifies the comparative assessment of their function. Without arguing for direct influence between the two communities, I view their use of pictorial art as part of a shared phenomenon of techniques of religious instruction. Just as the Jewish pictorial program, the Manichaean pictorial scroll is a product of Mesopotamian Late Antiquity. Although nothing Manichaean was discovered at Dura, it is well documented that Mani and his elects traveled across Mesopotamia (on the local trade routes), and thus must have passed through this city on their missionary journeys during a period of more than 17 years between the start of their activities in $240 \mathrm{CE}$ and destruction of the city sometime after $256 \mathrm{CE}$. In addition, there is a vast array of indirect ties connecting Mani and Dura, which, I argue, now include the didactic function of the doctrinal murals of the synagogue. Although this study is not concerned with the origin of the art under discussion-that is, the story of how they came about, including the technical aspects of the craftsmanship associated with the production of their respective mediums-it is likely that both had artistic ties to Ctesiphon. ${ }^{5}$ At Dura, pattern-books or model-books were used by local paintings workshops, ${ }^{6}$ some of which could have come from the nearest metropolis-Ctesiphon. ${ }^{7}$ The early Manichaeans also relied on workshops for the production of their books, including the Book of Pictures that Mani "ordered [...] to be painted" (Kephalaion 151, 371.25)—most certainly in Ctesiphon. Similarly, Mani's followers were noted for sparing no expense in commissioning their books from the most ac-

$4 \quad$ This monograph also assesses pictorial sources, including five images that survive from Uygur editions of Mani's Book of Pictures (ninth/tenth centuries) and 36 images that were adapted to other, non-canonical mediums (sculpture, wall painting, silk hanging scrolls, illuminated manuscripts, and mortuary banners) of Manichaean art in Uygur (mid-eighth to early eleventh centuries) and Chinese (twelfth to fifteenth centuries) contexts.

$5 \quad$ It is beyond doubt today that neither of them derived from illuminated manuscripts. For the critique of Weitzmann's theory on the origin of the Jewish murals at Dura, see e.g. Gutmann (1992); Hachlili (1998); Lowden (1992, 116-17); Williams (1999, 48-58). For the critique of Sundermann's theory on Mani's Book of Pictures, see Gulácsi $(2015,8-9,78)$.

6 "Pattern books" (Gutmann 1983, 104) and "modelbooks" (Wharton 1995, 48). The murals these artists produced were not frescoes painted onto wet plaster. Their paint, "powdery tempera," was brushed onto dry plaster (Gutmann 1992, 503). On painters working on multiple sites at Dura, see Jensen (1999, 184 86).

$7 \quad$ Model-books from the nearest metropolis, Ctesiphon, would explain the systematic use of Iranian visual language (garments, throne, investiture, and triumph motifs) throughout the panels of the synagogue. 


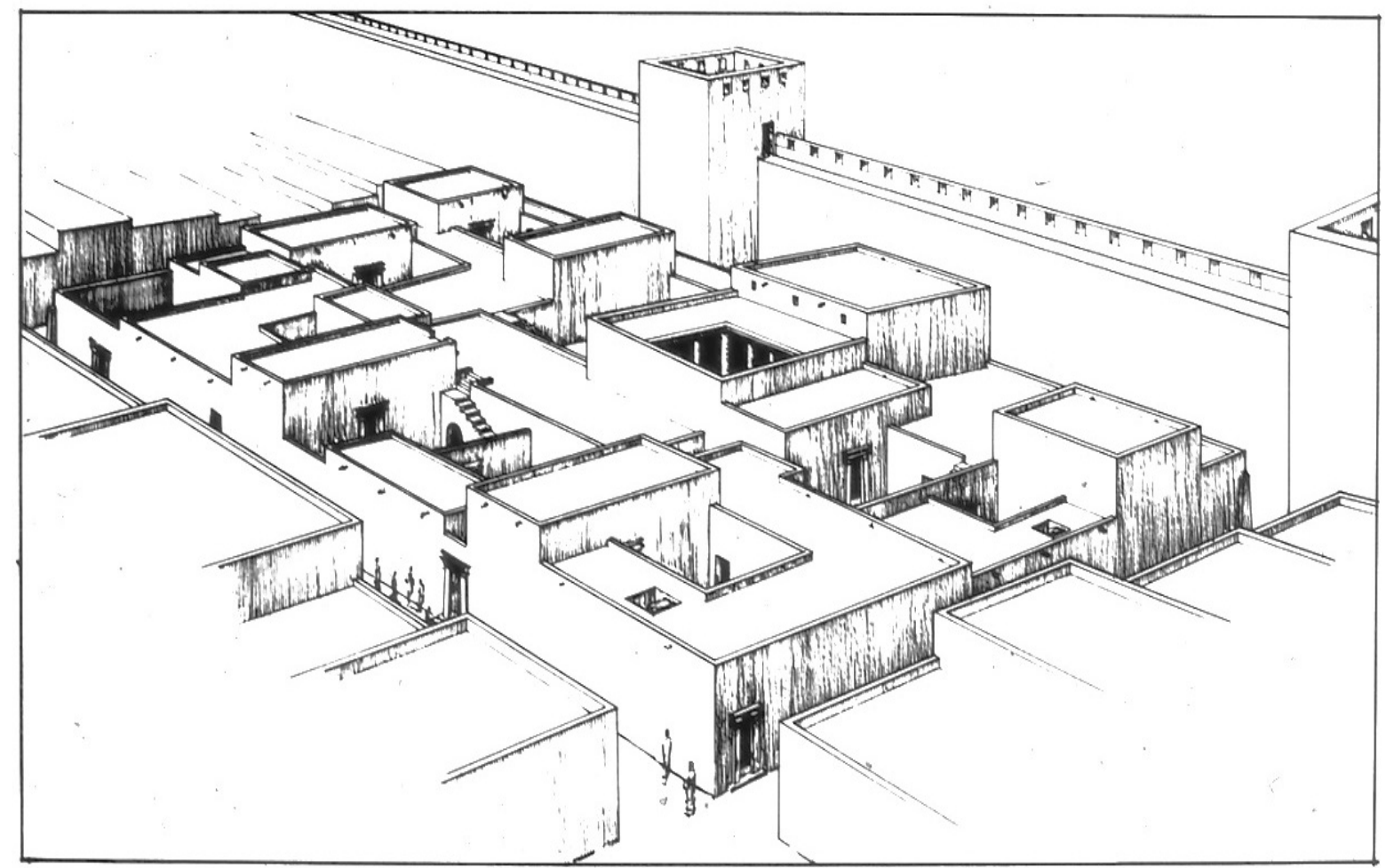

2a Isometric Reconstruction

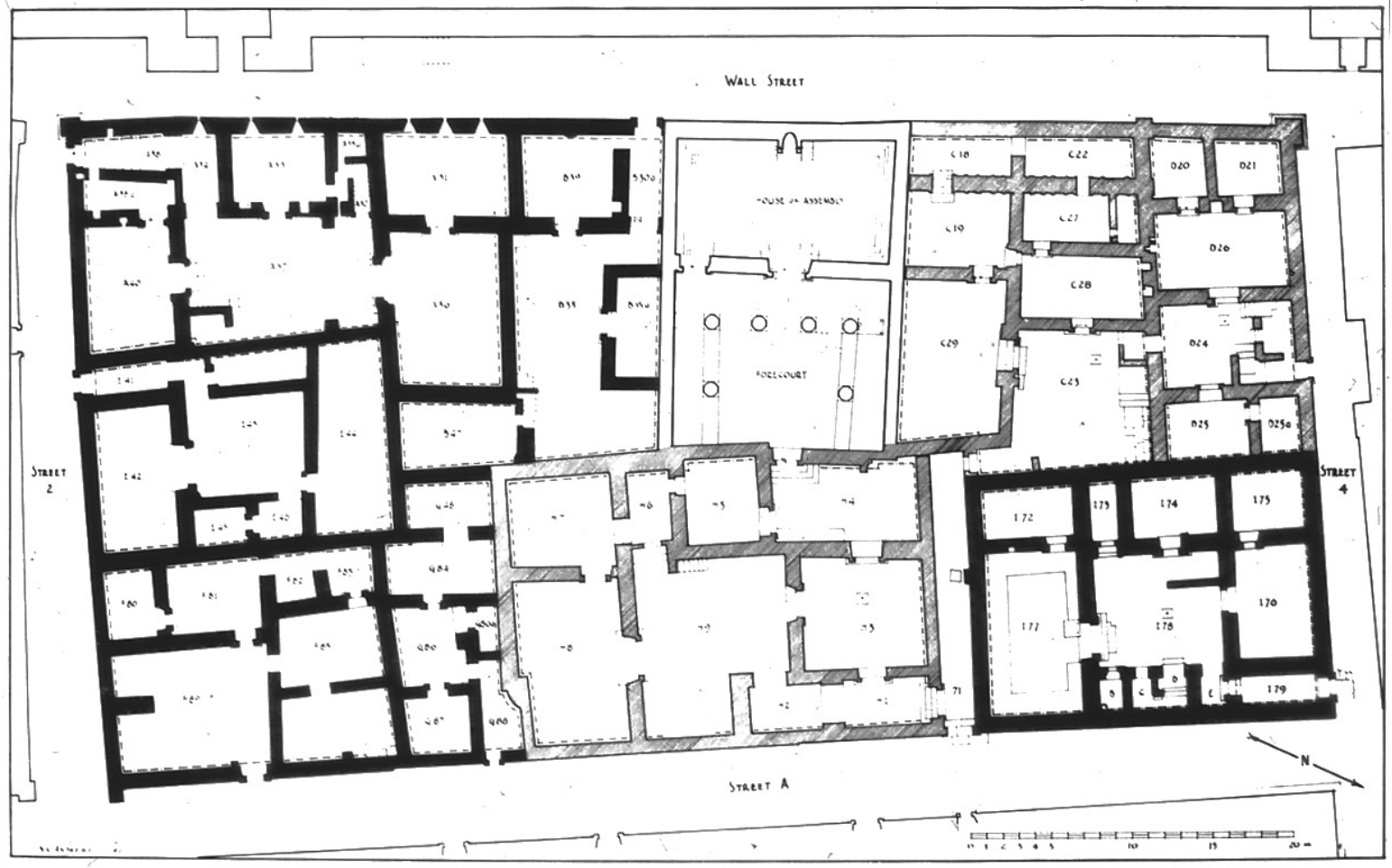

2b Plan

Figure 2 Block L7 of Dura with the synagogue, after Kraeling (1956, Plans II-III) 
complished calligraphers-600 years later in Abbasid Baghdad (Al-Jahiz, Kitab al-hayawan, before 847 CE; Reeves 2011, 226).

\section{Manichaean Didactic Art in Late Antiquity}

Mani's Book of Pictures is a new topic in Late Antique Studies, mostly because 'classical' (Latin and Greek) sources do not mention it-only Coptic, Syriac, and Parthian sources do, which have been traditionally marginalized and until recently were much ignored. Indeed, Mani's volume of paintings first became known not from the abovementioned ancient sources, but through studies of medieval Persian literature that started to supplement the previously exclusively Latin-based studies in this field in the late eighteenth century. ${ }^{8}$ The discovery of ancient Coptic as well as Parthian and Middle Persian Manichaean texts during the early twentieth century in the deserts of Egypt and East Central Asia further contributed to this emerging topic. Nevertheless, during most of the twentieth century, remarks about Mani's paintings remained dominantly philological in nature, confined to brief discussions, often in footnotes, in the critical editions of Parthian Manichaean texts. The first exception to this was a paper by Peter Nagel about Coptic and Syriac sources (Nagel 1981). Until the second decade of the twenty-first century, discussions of Mani's Book of Pictures were based on the above data and did not involve artistic remains. ${ }^{9}$

Mani and his elects were active in Mesopotamia on both sides of the border during the middle of the third century. Coptic Manichaean literature places Mani in Ctesiphon, Mesene, and Babylon, ${ }^{10}$ recording that Mani went "to the land of Babylon, Mesene, and Susiana" and taught three disciples along the flooded bank of the River Tigris on a spring day in Ctesiphon (Kephalaion 61, 152,21-155,5 and Kephalaia Prologue, 15.30-31; Gardner 1995, 160-61, 20 21 , respectively); and on another occasion, he held a debate with a member of a regional sect "in the midst of the land of Babylon," in southern Mesopotamia (Kephalaion 121, 288.22; Gardner 1995, 290). While writing about Manichaeism in the Roman Empire, Samuel Lieu concludes that Mani started to send his missionaries into Roman territories most likely as early as $244 \mathrm{CE}$, following the peace treaty between Persia and Rome that year; he points out that Mani's "Epistle to Edessa" (quoted in the Cologne Mani Codex) presupposes a community established there (Lieu 1992, 3, 4). Palmyra is mentioned in a Middle Persian text in connection with a mission lead there by a chief disciple (Mar Adda, M 2; Boyce 1975, 9:h2, 40), while a Coptic text discusses Mani in "Adiabene, and [on] the borders of the provinces of the kingdom of the Romans (Kephalaia, Prologue, 16.1-2; Gardner 1995, 21)."

Moreover, the late ancient sources considered in this study document specifically the use of Mani's Book of Pictures in the region to the immediate east of Mesopotamia during the middle and the second half of the third century. Among their geographical references closest to Mesopotamia are the city of Holvān, located northeast of Seleucia-Ctesiphon along the road to Hamadan in the Zagros Mountains, in what is today the Hulwan province of modern

8 Latin polemical texts did not know about Manichaean pictorial art. Augustine of Hippo even noted the aniconic nature of the religion in the form known to him (Contra Faustum 20:9 and 20:10).

9 For an overview of history of research, see Gulácsi $(2015,3-12)$.

10 Ctesiphon (Kephalaion 76, 183.14-15; cf. Hom. 44.16; 67.14; 76.28), Mesene (Kephalaion 76, 186.6-7; cf. Hom. 44.14; 76.27), and Babylon (Kephalaion 76, 186.25). See Gardner (1995); Pedersen (2006) respectively. 
Iran (Boyce 1975, 9:40); ${ }^{11}$ and Gondeshapur (Syro-Aram, Bēth Lāpāț), whose Sasanian ruins are still visible near the modern city of Dezful in the province of Khuzestan, north of the Persian Gulf along the western border of Iran. ${ }^{12}$ Other locations include Abarshahr, a northern province of the Sasanian state that translates as the 'Upper Lands,' that is, the old Parthian homeland, known today as Ancient or Greater Khorasan (Boyce 1975, 9:40n3; Klimkeit 1993, 217n19). During Mani's time, the latter region constituted the northeastern provinces of the Sasanian empire and included cities such as of Merv (a major oasis city and religious center along the Silk Routes, located today in Turkmenistan) and Zamb (modern Karkhî) on the left bank of the Oxus River (Pers. Amu Darya), about 220 miles northeast of Merv. ${ }^{13}$ The sources in question are diverse in term of their preservation. Some are primary texts in their original Iranian languages. Others are primary texts that originally were written in Syriac, but survive in the Coptic translation. One text was written in Syriac as a secondary, outsider account.

The only secondary source from the Mediterranean region that mentions Mani's Book of Pictures was written by Ephrem Syrus (306-373 CE), who lived in the Syrian city of Nisibis (modern Nusaybin in southeast Turkey) and later, after the Sasanian capture of the city in 363 $\mathrm{CE}$, became active in the Syrian refugee community in Roman Edessa. He spoke and wrote in Syriac. His books include some of the earliest anti-Manichaean texts, in poetic (Hymn Refutations) and prose (Prose Refutations) form, that target the major competitors of Ephrem's version of Christianity in Syro-Mesopotamia-the followers of Bardaisan (154-222 CE), Marcion (second century CE), and Mani. Despite its polemical tone, Ephrem's passage about Mani's Book of Pictures in his Prose Refutations is highly relevant, since its author lived within a century of Mani and shared with him not only temporal closeness but also a common linguistic and cultural environment. Moreover, Ephrem quotes directly from Manichaean texts and credits Mani's disciples as his sources of information.

The Coptic Manichaean sources are well-preserved papyrus codices that were discovered in Egypt during the 1920s at a site known as Medinet Madi in the Faiyum Oasis, and subsequently sold on the antique book market. They are the thickest ancient codices (over 400 pages) known to date. They were made locally, written in the Coptic language and script, sometime between the late third and late fifth centuries as translations of earlier works. One such codex, passages of which will be considered below is the Kephalaia of the Teacher (Coptic/Gr. kephalaia 'chapters') in the Berlin State Library that was composed, most likely in Syriac, by an unnamed early disciple sometime during the late third century with the intent to preserve Mani's oral instructions to his followers (Gardner 1995, xviii-xix). Another is the Homilies in the Chester Beatty Library in Dublin. It dates from the second half of the fourth century, but contains a collection of sermons that were originally composed in Syriac by early disciples in Mesopotamia probably soon after the death of Mani (274 or $277 \mathrm{CE}$ ), to which the manuscript refers. ${ }^{14}$ Thus, these Coptic texts are regarded as highly authoritative early primary sources in which Mani's words take the reader back to mid-third-century Mesopotamia.

The Iranian Manichaean sources are the closest to Mani's time. They survive as fragments

11 (Aram.) Māhōzē, (Ar.) al-Madā'en (lit. 'the Cities') reference the metropolis formed by Seleucia and Ctesiphon on the opposite sides of the Tigris River in present-day Iraq. Hamadān or Hamedān (Gr. Ecbatana) is the capital city of Hamadan Province of modern Iran (Le Strange 1930, 191).

Founded in ca. 260 CE by Šāpūr I and built by prisoners of war from the Roman army, Gondeshapur was the capital of Sasanian Knūzestān and occasionally the location of the Sasaian royal court. Bahrām I (r. 273-76 CE) held his court there during Mani's imprisonment and death, see Morony (1989).

13 The name Zamb (later Zamm) connotes 'shore' after the Persian noun damb, dam (Boyce 1975, 9:49; Klimkeit 1993, 268n26).

14 For other proposed dates to the fifth century, see Pedersen (1993, 80-82). 
of texts that were subsequently copied into paper codices that were found between 1902 and 1914 among the ruins of Kocho (located near the Turfan Oasis in the Xinjiang Uygur Autonomous Region, China) and its neighboring archaeological sites by Prussian expeditions. Today, they are archived in the Turfan Collection of the State Library in Berlin, each catalogued under a capital letter indicating its script. "M" stands for fragments with Manichaean script writing. Considered below are Parthian and Middle Persian texts about Mani's Book of Pictures. They include letters on missionary history (M 2, M 5569, M 5815), written during Mani's time and shortly after his death, as well as transcripts of image-based sermons (M 219, M 4570) and a teacher's notes for an image-based sermon (M 35) that date from after Mani's passing. These texts were composed by the first generation of elects in Mesopotamia and West Central Asia during the middle and the second half of the third century. In the course of their subsequent use, they were copied into anthologies of Manichaean literature. Thus, they preserve late ancient content in manuscripts made during the Uygur era of Manichaeism (752/755-1024 CE), when the agricultural and trading center of Kocho functioned as the winter capital of the Tien Shan Uygur Kingdom (866-1209 CE).

These late ancient Manichaean sources convey that Mani and his followers had a distinct understanding of what a book was, which somewhat differed from modern associations with the word. Under 'book,' they meant any portable medium, made from locally available materials and formats, to store records of thoughts or ideas. The record itself could either be verbal (i.e., written by using a suitable writing system and a language) or exclusively visual (i.e., painted or drawn by using a locally available painting style and a locally comprehensible iconography). The visual record could be a diagram (in order to illustrate structure), a portrait or an icon of a deity (to show the likeness of the being), or a narrative scene (in order to reflect time, change, or events). ${ }^{15}$ As is to be expected from a missionary religion equipped with a volume of didactic paintings, multiple copies of the Book of Picture are attested to in the early history of the Manichaean missions. In a sense, the Manichaeans had just one (Book of) Pictures, just as they had only one Gospel, Treasury of Life, Pragmateia, (Book of) Mysteries, (Book of) Giants, (Book of) Epistles, (Book of) Psalms, and (Book of) Prayers in their canon (Homilies 25). But multiple copies of these books were needed, even within one community. Already during Mani's time, their reproduction is attested. Making copies of the canon's written books and its one pictorial volume was standard activity throughout Manichaean history.

These sources also convey that Mani instituted the employment of visual art for teaching in the religion he founded. In a deliberate and definitive manner, he established the systematic exposition of his complex doctrine in a set of images stored in a book format. He intended his paintings to be a standard part of his legacy-a visual record of a worldview that he also explained in his writings. The volume that contained these images was titled the (Book of) Picture(s): Hikōn in Coptic, Yuqnā in Syriac, Ārdhang in Parthian, and Nigār in Middle Persian. ${ }^{16}$ This book itself was a work of art and so, too, were the individual images it containeddiagrams, icons, and pictorial narratives. As all the other holy books of Mani, this volume had a doctrinal content, was created with the intent to preserve the authenticity of Mani's teachings, was stored with them in the library room of the manistans, and functioned as a reference work and a didactic tool.

Manichaean art does not survive from third-century Mesopotamia, with one remarkable ex-

15 The solely pictorial nature of the Book of Pictures is unambiguous in the sources; see Gulácsi (2015, 279-312 and Tab. 5/5)

16 Although the title is not attested in Greek sources, Manichaean studies scholarship has routinely employed an assumed Greek version (Eikon) in reference to Book of Pictures. 
ception: Mani's own rock crystal sealstone, from what originally was a pendent seal, housed in the Bibliothèque nationale de France. ${ }^{17}$ Recently, however, four fragments of Uygur editions of Mani's Book of Pictures (containing a total of five images) were identified in the collection of the Museum für Asiatische Kunst in Berlin (previously Museum für Indische Kunst, Gulácsi 2015, 214-26). Since they were made about 700 years after Mani, during the ninth or tenth century in Kocho, their artistic language is Central Asian, and not pertinent to this study. It is their doctrinal content, attested to have originated in mid-third-century Mesopotamia, that offers the point of comparison to be considered below.

The Mesopotamian pictorial roll mentioned in Manichaean sources is an elusive painting format in ancient art. Unlike codices with Coptic, Greek, and Latin texts, handscrolls that contained third-century 'copies' and later editions of Mani's collection of images do not survive from the first 700 years of Manichaean history, and thus will not be considered in this study. The earliest Roman record of a pictorial scroll dates from about 150-years before Mani. It is referenced in a sculptural interpretation of a pictorial roll on Trajan's Victory Column (113 CE, Rome) where a spiral frieze, which winds 23 times from base to top around the 35-meter tall shaft, portrays a continuous narrative of the Dacian Wars. ${ }^{18}$ Physical examples likely related to ancient pictorial rolls include a Byzantine imperial handscroll that combines a pictorial program with small excerpts of a biblical text on a parchment scroll about the prophet Joshua, ${ }^{19}$ and a twelfth- or thirteenth-century copy of a Roman map containing useful information about the most-traveled places and roads between Western Europe (Spain, England, France) and South Asia (the Indian peninsula and Sri Lanka) between the first and fourth centuries, known as the Peutinger Map (Levi and Levi 1978; Ball 2000, 123).

The practicalities of using Mani's Book of Pictures for religious instruction in ancient Mesopotamina is well understood. As all pictorial handscrolls, this, too, was a private and elite medium. It would have been placed on a solid surface and opened up for viewing in approximately two-feet-long increments, never in full length. Using the handscroll in the course of a teaching would have required a person to operate the scroll by rolling it from scene-toscene as the instruction proceeded. Once the sermon was completed, the painted handscroll would have been rolled up and put away for storage, much like textual scrolls and codices. The nature of the handscroll format would have allowed only a relatively small group of people to listen to an image-based sermon, requiring them to be close to the scroll to see the images. Therefore, not only the value of such a painted scroll, but also the intimate nature of its viewing would have made the teaching and learning with the Book of Pictures a truly special occasion and a rare event. ${ }^{20}$

17 Mani's sealstone is a double-sided clear rock crystal carved into the shape of a cabochon and originally set in gold to fulfill a dual function. Its curving side was a seal, incised with a negative inscription and an image. Its flat side was an engraved gem pendent, on which the carving showed through from the other side as a legible inscription and the main figure facing to the right (Gulácsi 2010).

18 The theory that the design of Trajan's Column imitates a "book-scroll" is discredited today due to the fact that such a pictorial format remains unattested in Roman art. Historical narration-painted or carved in stacked registers of frieze bands-is known only from earlier funerary chambers as well as later triumphal monuments (see Kuttner 2015).

19 The origin of the Joshua Roll (Constantinople, Bibliotheca Apostolica Vaticana) remains debated: Kurt Weitzmann suggested that this mid-tenth-century scroll was a product of the "Macedonian Renaissance" with no ancient prototype. Meyer Schapiro saw in its tenth-century picture frieze an ancient prototype transmitted via intermediaries. John Lowden argued that it was an antiquarian copy of a seventh-century original. For an overview, see Lowden (1992, 105-22).

20 The horizontal codex format (best known today from Kufic Korans) is also attested among the Uygur editions of Mani's Book of Pictures from ninth/tenth century Kocho; see Gulácsi (2015, 220-26 and Fig. 5/4). 
The Manichaeans had religious buildings in ancient Mesopotamia. Established by Mani himself, the manistan was an institution of learning, ritual, and medical care. Based on its functions, it may be best compared to either a temple complex (but built on a modest scale and with a library and an infirmary in it) or a monastery (but without any permanent sacerdotal living quarters). ${ }^{21}$ There is no evidence that members of the sacerdotal class spent their lives in manistans in a monastic fashion during this time. The elect lived with the auditors, who hosted them for short periods of time and, in return, gained social prestige and merit for a good rebirth. This arrangement is similar to the one followed in Jainism in northwestern India, visited by Mani early in his career. ${ }^{22}$ It is possible that certain rooms of the manistan started to feature figural decoration at one point, since a Manichaean wall painter was mentioned from early sixth-century Constantinople in a Byzantine source. ${ }^{23}$ But these later developments are not considered in the comparison between Manichaean and Jewish employment of didactic art that follows. This study keeps it focus on Mesopotamia during the middle of the third century.

\section{Comparative Assessment of Duran Jewish and Third-Century Manichaean Art}

\section{Doctrinal Content}

The pictorial program of the Dura synagogue and Mani's Book of Pictures are analogous to one another in the sense that they both constitute self-standing visual libraries of religious teaching. By assembling them, the Duran Jews, just as the first Manichaeans, curated a conscious pictorial collection of doctrinal expositions-significant in quantity, systematic in coverage, and deliberate in artistic language. As a whole, the sum of paintings, which survive in the Jewish case and are documented in the Manichaean case, convey core themes of doctrine, showcasing a large group of select subjects on prophetology, eschatology, and polemics that were deemed important by the leaders of their communities. In both cases, the doctrinal significance of each individual image is attested by the existence of its written/verbal account, housed separately, in the holy texts of the religion.

The complementary duality of text and image was crucial to the first Manichaeans. Documentary evidence attests that Mani fostered a religious culture in which his wisdom, his visions, and his insights would be conveyed and recorded in two equally significant ways-in a written form in his books and in a painted, artistic form in his pictures. The deliberateness of this act is attested by Ephrem, who quotes Mani as he writes: "I have written them (the

21 A Parthian fragment (M 4579) notes that, during his last journey, Mani sought shelter in a 'mānistān building' in the city of Ohrmizd-Ardaxšihr. A Middle Persian fragment (M 2) states that Adda founded many manistans during his missions to the Romans "up to Alexandria." The etymology of the Middle Iranian noun manistan has been explained in various ways (including the verb man- 'to think' and even the personal name Mānī), but it likely derives from either the verb māndan-/mān- 'to remain, to stay' or the noun mān 'house, dwelling' (Utas 1985, 655-57). For later sources about the various rooms of the manistan, specifying the function of each room, including its library that held the "scriptures and the Book of Pictures," see Gulácsi (2015, 116-17, 118-26).

22 Jain influence has been noted in Manichaean attitudes of non-injury (Jones 2010, 383-98); also see Gardner (2005); Deeg and Gardner (2009).

23 The earliest textual evidence about murals painted by a Manichaean elect in Constantinople is preserved in Theophanes Confessor's Chronicle on the events of 506/7 CE (see Gulácsi 2015, 42-44). Physical evidence of painted walls in later manistans survives from two buildings from tenth-century Kocho (see Gulácsi 2015, 138-41, 226-33). 
teachings) in books and painted them in colors." It remains unknown what gave this idea to Mani, but an advantage of it is stated in Kephalaion 151:

As for this [immeasurable] wisdom I have written it in the holy books-in the great [Gospel] and the other writings-so that it not be altered [after] me. Just as I have written it in books, so [I have] also ordered it to be painted. [...] For all the [apostles], my brothers, who have come before me, [have not written] their wisdom in the books as I have written it. [Neither have] they painted their wisdom in the Hikōn (Copt. 'picture, image' < Gr. eikon) as [I have painted] it. (Kephalaion $151,371.20-30)^{24}$

Mani is not talking about making an illuminated manuscript (that medium is unattested among the Manichaeans for another 700 years). What Mani claims here is committing his teachings to two different kinds of records: writing them down in text books and painting visual representations of them in a solely pictorial picture book. Ephrem specifies the format of the latter as a scroll (Syr. mgalltâ)—a pictorial roll. ${ }^{25}$

Although physically separate from one another, the two different kinds of records of Mani's doctrine-verbal/written vs. visual/painted-were routinely mentioned together. The Book of Pictures was used in close connection with the canonical literature. The early sources note the practice of pairing the painted book with one of Mani's written books and taking both for missions across the western regions of Sasanian Empire. One Middle Persian text mentions this in connection with Mani launching a new mission to Parthia, sometime during the 260s CE (M 2):

And when the Apostle of Light (Mani) was in the provincial capital of Holvān, he let the teacher Mār Ammō come, who knew the Parthian script and language and was familiar with [...] He sent him to Abarshahr. He [Mār Ammō] went to Abarshar with prince Ardabān ${ }^{26}$ and brother-scribes, with books and the Nigār. He said, "Blessed be this religion. May it flourish through teachers, hearers, and soul-service. (Sundermann 2005, 382-83)

Other sources give specific titles. Mani's Gospel is paired with the Book of Pictures in a Parthian text (M 5569) about the events surrounding Mani's passing in prison, written by Uzzi, an elect with the rank of a Manichaean Teacher. It notes that Mani carried his Gospel and his Ärdhang on his last journey in 274 or $277 \mathrm{CE}$, when he was imprisoned in the town of Gondēšāpur; and that after Mani's death, these two volumes were taken to Sisin (Sisinnius), who succeeded Mani in heading the Manichaean Church until his own martyrdom in 291/2 CE (Boyce 1975, 9:3, 48). Another text, a Parthian letter about another early mission (M 5815), pairs the Book of Pictures with the Book of Giants:

And you should know this: When I came up to Merv, I found all the brothers and sisters to be devout. And to dear brother Zurvāndād, I am very very grateful,

$24 \quad$ Middle Persian (M 5794) and Sogdian (Ch. 5554) versions of this passage survive from Kocho (Klimkeit 1993, 216).

25 Ephrem, Prose Refutations 126.31ff: “According to some of his disciples, Mani also painted (Syr. șār) (the) figures of the godless doctrine, which he fabricated out of his own mind, using pigments (Syr. $b^{e} s a m m \bar{a} \bar{e}$ ) on a scroll (Syr. mgalltâ)" (Reeves 1997, 262).

26 Boyce notes that the Parthian prince Ardabān belonged to the house of the Arsacids, and thus he was a kinsman of Mani's (Boyce 1975, 9:40; also cited in Klimkeit 1993, 217n20). 
because he, in his goodness, has watched over all the brothers. And I have now dispatched him to Zamb, and I have sent him to dear Mār Ammō and to (the province of) Khorasan. He [brother Zurvāndād] has taken the (Book of the) Giants and the Ärdhang with him. I have made another (copy of the Book of the) Giants and the Ārdhang in Merv. (Klimkeit 1993, 260) ${ }^{27}$

It is well attested that passages from Mani's writing were read aloud as part of regular sermons, while images from the Book of Pictures were shown in the course of image-based sermons. Mani's writings might have also functioned as a verbal resource for an elect, who could consult them to refresh his understanding or to be inspired by Mani's words before giving a sermon built around the visual record of the doctrine displayed in front of the auditors.

A comparable duality of doctrinal communication is evidenced at the Dura synagogue. Once the three registers of narrative scenes were added to the plastered interior walls (Kraeling $1956,15)$ in $244 / 245$ CE under "the leadership of the priest Samuel son of Yeda'ya," 28 the Jews of Dura also had two means of conveying doctrine associated with their synagogue that were distinctly different in nature and physically independent of one another. From then on, their meeting hall not only held the written/verbal collection of doctrine (rolled up in a scroll chest) placed in the dedicated space of its aedicula, but also included a painted/visual collection of the biblical narratives displayed panel by panel on all four walls in three registers. This duality, however, is lost in most studies of the synagogue's pictorial program, owning to a focus on the written Law. To be fair, the interior architecture and, to some extent, the pictorial program itself do prioritize the scriptures, and scholarship has readily picked up on it. For example, Levine's assessment of the doctrinal themes starts with "the sanctity of the Torah" as expressed through the Torah aedicula (Levine 2012, 112-13). Indeed, the Torah remains the main visual focus in the renovated meeting hall through the protruding design of its sizable and elaborate shrine, approximately centered on the wall opposite the entrance. ${ }^{29}$ The scripture was placed into its niche ${ }^{30}$ under the white motifs of a niche-head (conch and rolled up curtain) and protectively framed by a pair of side columns and topped with an arched façade that crowned the shrine with three groups of small images: the frontal image of the temple in the middle, flanked by a narrative scene with the sacrifice of Isaac in the left and ritual implements on the right (a lighted menorah, a lulav, and an ethrog). The visual prominence of this symmetrical structure continues in the symmetry of the reredos above it on the wall (two large central and four small wing panels), in sharp contrast with the distribution of the rest of the panels. Steven Fine emphasizes that a reverence toward the Jewish scripture

27 Boyce provides a detailed discussion of the letter in her Reader (Boyce 1975, 9:48-49). The authenticity of this text is not in doubt.

28 This name and title are preserved in the Aramaic inscription on ceiling "Tile A" (Kraeling 1956, 263).

29 The aedicula was set up this way in the meeting hall, when the originally private dwelling was converted to a synagogue sometime between 165 and 200 CE (Kraeling 1956, 327). It is the most elaborately accessorized Torah niche known from ancient synagogues (see Hachlili 1976, esp. 43, and 52-53), thought to be "the point of orientation of the worshipers at prayer" (Kraeling 1956, 54).

30 As indicated by its size, the niche of the aedicula could display only the scroll(s) used for the reading on that day. The niche opening is $0.84 \mathrm{~m}$. wide and $1.48 \mathrm{~m}$. high to the top of the arched opening, imbedded 0.50 m. in the rubble wall (Rostovtzeff et al. 1936, 320; Kraeling 1956, 16, 54-55). The full set of books was kept elsewhere in the complex; and what they were remains unknown. Charles Perrot notes that a standard set included "the five scrolls of the Tora, kept in a portable chest or a special niche (or again 'in a corner' B.T. Kiddushin 66a, or in jars at Qumran). All synagogues must surely have possessed the whole Tora in five volumes (Aristeas, second century BCE, says 'cases') and some other Bible scrolls, like Isaiah and the Twelve Prophets, and no doubt the Psalms. These were the books most in use. The Palestinian synagogues, small and numerous could probably not afford all the scrolls, which were in any case expensive" (Perrot 1990, 155). 
is "projected onto the walls of the synagogue, pointing to its centrality in the ritual life of the community" $(2005,58)$. He draws attention to specific images in this role, such as the depiction of Moses (at the right corner of the façade), holding an open scroll as if he were reading from the scriptures; the text of the Moses scroll bleeding through to emphasize the importance of the scripture; and the Ark of the Covenant (further to the right in the same register) shown as a tall gold chest with a rounded top in the form of a Torah shrine. ${ }^{31}$

The pictorial program of the synagogue is in itself an esteemed depository of doctrine. Stories familiar from the Hebrew Bible are readily recognizable in the murals, which provided the impetus for matching their contents to texts. Most publications could only depict the visual catechism of these paintings as illustrations of these biblical and rabbinic texts. ${ }^{32}$ In Annabel Wharton's critique of this prevailing scholarly trend, they "intend on identifying the text that explains the image" and assert "the priority of the text over the image" $(1995,45,48)$. The murals, however, are fixed to the walls. They are physically independent of the scriptures, neither displayed only while the text is read nor put away when the text is rolled up. Thus, the question here is not with which biblical passages the paintings can be matched, but rather what doctrine they showed. Levine's approach to their overall doctrinal content departs from previous interpretations in the sense that it starts with the paintings and "evoke[s] literary sources only secondarily." By keeping this focus, he is able to see beyond textual parallels and discern the main themes of visual catechism on the most intact, west wall. ${ }^{33}$ This approach is worthy of a closer look because the main themes portrayed by these Jewish murals accord with certain documented themes of Mani's Book of Pictures. Both were concerned with (1) prophetology, (2) eschatology, and (3) polemics.

Prophetological teachings are well articulated in Mani's writings, including two main subjects that are specifically attested for the Book of Pictures. ${ }^{34}$ One of them concerns Mani's heritage as a prophet. Mani saw himself as a successor of past teachers, who acted upon divine inspiration to serve as religious leaders within their own communities. He called them "messengers," by which he meant human envoys of God. He built them into a prophetological doctrine, integrating some of their teachings into a uniquely Manichaean synthesis (Tardieu 2008, 13-19). Mani identified himself as one such human envoy through the Syriac term $\check{s}^{e} l i \bar{h} \bar{a}$ ('messenger') ${ }^{35}$ on his sealstone and the starting formula of his letters. To express the

31 Fine $(2005,58-59)$ also points out the presence of this correspondence in rabbinic literature. The Art of the Covenant is part of three panels: The Battle of Eben-Ezel (NB 1), The Ark in the Land of the Philistines (WB 4), and the Consecration of the Tabernacle (SB 1) (see Kraeling 1956, 98, Fig. 29, Plates LIV, LVI, LX).

32 E.g. Gutmann tabulates the panels' textual identifications and the scholars who prosed them $(1984,1315-$ 22); Kraeling surveys thematic parallels between the panels and the Bible, as well as the Midrash and the Targum (1956, 349-54).

33 Levine reasons: "Those themes appearing repeatedly on this wall, we can assume, would have represented core ideas and beliefs of the Duran Jewish community as a religious and ethnic group." In no particular order of hierarchy, he identifies four on the west wall: (1) "the centrality and sanctity of the Torah," (2) "the promise of Moses," (3) "the centrality of the Tabernacle-Temple" and (4) "messianic/eschatological themes" (2012, 112-17).

34 Concerning the doctrinal content of Mani's Book of Pictures, early textual sources allude to what the images showed, which convey six themes: (1) Dualism (i.e., Light and the Darkness), (2) Soteriology (i.e., soul departing body, judgment after death, the fate of the righteous, the fate of the sinner), (3) Prophetology (i.e., the Four Primary Prophets of Manichaeism, the Life of Jesus), (4) Cosmology, (5) Eschatology (i.e., Jesus' second coming and the Great Fire), and (6) Polemics (i.e., false beliefs of idol worship) (see Gulácsi 2015, 46-47, 96-96, 316).

35 In Parthian and Middle Persian, he most likely used the noun frēštag 'messenger, apostle, or angel' (DurkinMeisterernst 2004, 3.1:3.1:160). 
religious and philosophical rootedness of Mani's message ${ }^{36}$ the founding prophets of Zoroastrianism, Buddhism, and Christianity are grouped with Mani in the text (Kephalaion 1, M 42) and on the artistic representations of this teaching, including a fragmentary diagram surviving from an Uygur edition of the Book of Pictures that depicted the "Four Primary Prophets of Manichaeism" (Gulácsi 2015, 356-74, 2017b). The other prophetological subject attested from the Book of Pictures was the life story of Mani's personal savior, Jesus, that Mani taught

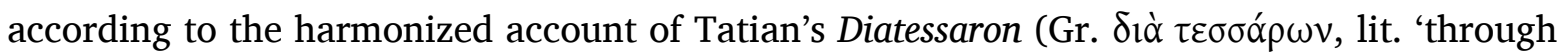
four') - the earliest known gospel harmony, dating from the 170s CE. Composed in Syriac, this gospel text remained standard in the Syriac-speaking world until the late fifth century. The earliest direct evidence on the use of the Diatessaron in Mesopotamia is provided by "the Greek Fragment," found in the Church at Dura. Dating from before the mid-250s, it is one of the earliest Christian manuscripts known today. ${ }^{37}$ As such, this fragment gives a date for the circulation of the Diatessaron in the region that coincides with the activities of Mani. ${ }^{38}$ The life of Jesus narrated with diatessaronic characteristics survives not only in a sermon of Mani (Kephalaion 1, 12.21-13.11), but also on a fragmentary series of small vignettes that were adapted to an Uygur Manichaean illuminated service book from a rendition of this teaching in a now-lost earlier edition of Mani's Book of Pictures (Gulácsi 2008).

A similar kind of prophetology—where human messengers of God play defining roles in the history of their religions-is conveyed in the murals of the Dura synagogue. While almost all panels center on a figure of religious significance (Abraham, Aaron, David, Elijah, Esther, Ezekiel, Jacob, Job, Solomon, Samuel, and Saul), the focus on Moses is striking. Levine stresses that Moses dominates the west wall and his centrality is "inextricably intertwined with the sacrality and centrality of the Torah" (2012, 113-14). The three narrative scenes dedicated to Moses's life claim approximately one-third of the west wall-one panel in each register. Moses's birth story is in the lower right, his parting the sea is in the upper right, and his miracle at the well of Be'er is along the left edge of the middle register. Moreover, Moses is also portrayed on his own four times in the wings of the reredos directly above the Torah shrine. As convincingly argued by Erwin Goodenough, Moses is not simply one among many biblical teachers, but the supreme priest of all time- "the Lawmaker of the Jews or rather the author of the mystic Torah" (Goodenough 1953, 9:119). Moses is shown in such a role when portrayed with the burning bush (upper right), receiving the Law (upper left), reading the Law (lower right), and offering a final prayer (lower left). In this visual emphasis on Moses, the pictorial program produced by a Hellenized diaspora community at Dura is close to contemporaneous Manichaean prophetology, where one prophet, acting as a human messenger of God, founds

36 Textual sources mention ten prophets from West Asia: Mani, Jesus, Zoroaster, and Shakyamuni, plus various Jewish prophets (Adam, Seth, Enos, Noah, Sem, and Enoch). No text names all. One early Chinese Manichaean account (731 CE) also mentions Lao-tsu (Tardieu 2008, 13-19, Fig. 1).

37 It contains fourteen Greek lines from a harmonized Passion narrative that retains linguistic traces of a Syriac language original, suggesting that it is a translation of Tatian's work (Petersen 1990, 413). Kraeling hypothesizes that the parchment scroll to which the fragment belonged was made somewhere in Mesopotamia, possibly in Edessa (Kraeling 1935, 7).

38 In a series of studies between 1968 and 1993, Gilles Quispel argues that the Manichaeans preserved the most authentic version of Tatian's Diatessaron in the Latin-speaking part of the Roman Empire (Quispel 1993). Unlike the Diatessaron in Syriac Christian use, where its content was gradually brought into greater alignment with the standard texts of the Greek gospels, the Manichaean version of the Diatessaron in the Latin West remained 'archaic' and 'wild,' since the Manichaeans were under no pressure to 'vulgatize' or 'domesticate' it. Direct quotations from Tatian's prose in the Parthian translation survive from Manichaean Kocho (Sundermann 1968). 
a religion (Goodenough 1953, 9:113-23; Levine 2012, 114-15). Ezra and Abraham are other possibilities for the lower two panels (Kraeling 1956, 227-39).

Eschatology is another theme that overlaps between the doctrinal images of these two communities during the middle of the third century. Manichaean salvation theory encompasses the entire universe. Its doctrine is light-centered, for the liberated divine essence or soul can only be a form of light. In Mani's teachings, God created the universe as a mechanism to heal the devastation caused by the catastrophic mixture of light and darkness and to liberate the divine essence from its mixture with evil. Thus, salvation is integral to cosmic history (precreation, cosmogony, theogony, and eschatology), just as it is to cosmic structure (cosmology, theology, and prophetology). Cosmic eschatology was portrayed in Mani's Book of Pictures. A Parthian fragment written about the Book of Pictures (M 35) preserves two passages about the eschaton of the universe. Both deal with events that take place at the end of time and include Jesus' second coming, which remains a largely unexplored theme of Manichaean teaching, and the "Great Fire" (also known as the "World Fire") that consumes the universe at the end of time. No known visual records of these scenes survive. ${ }^{39}$ Mani's teachings about the Realm of Light/God and the full restoration of the Realm of Light at the end of time are well attested in Manichaean literature. No known texts mention these subjects in connection with the Book of Pictures. Nevertheless, later Manichaean art that was produced based on the Book of Pictures about a 1000 years after Mani in southern China still portrays an image of the divine court in the Land of Light-showing the enthroned Father of Greatness (God) and his two attendants (the Mother of Life and the Living Spirit) surrounded by the twelve aeons-in a composition not unlike the assembly of the messianic court in the reredos at Dura (Gulácsi and BeDuhn 2011-2015, 69-70).

Eschatology receives significant attention in the pictorial program of the renovated synagogue. Its prominence is direct in some panels and detectable in subtler ways in others. (1) Levine emphasizes how messianic teachings are depicted on three panels (2012, 117; cf. Kraeling 1956, 215-27). One of them is the extensive parable about the resurrection of the Jewish state (i.e., the "Destruction and Restoration of National Life"), a teaching that is also described in Ezekiel's vision of the Valley of the Dry Bones (Ezek. 37), shown in three parts across the entire bottom register of the north wall (NC 1) (Levine 2012, 117; cf. Kraeling 1956, 17981). Two eschatological panels were chosen for the reredos on the west wall. This prestigious location underlines their utmost significance. The upper panel depicted a messianic court-a throne-room scene with a regal image of an enthroned figure (possibly David or the messiah) surrounded by an entourage of thirteen men "representative of the eleven tribes and the two half tribes that together make up the entirety of the Hebrew nation" (Kraeling 1956, 226). The panel below portrayed Jacob blessing his sons and grandsons while David plays a harp for animals (Kraeling 1956, 221-25). Herbert Kessler suggests that together, these two functioned as a "bipartite anagogical design. In the lower panel were reminders of the historical promises, Jacob blessings, David, and the branch; above was pictured the fulfillment of those promises, the Messiah king, the men who would rebuild the Temple and reinstitute the cult, and the tribes of Israel returned to their kingdom."40 (2) Carl Kraeling notes that some panels on the west wall imply a messianic message by alluding to the rebuilding of the Temple

39 More records discuss individual human eschatology (soteriology) in connection with the Book of Pictures (Gulácsi 2015, 316-55).

40 In Kessler's view, the depiction of the messianic king in this scene countered Christian claims that the messiah had already come (Weitzmann and Kessler 1990, 169). Paul V. M. Flesher argues against the messianic interpretations of the reredos (Flesher 1995). 
through a Tabernacle-Temple theme that runs horizontally across the middle register passing through the axis of the reredos just above a Temple motif in the façade of the Torah shrine. ${ }^{41}$ In the more cautious view of a historian of Judaism, Levine concludes that while these visual references reflect a deeply rooted "loyalty" to the Jerusalem Temple, "there is no way to determine how this third-century community related to the Temple, which was destroyed 150 years earlier-as a historical memory, a religious symbol, a future hope or some combination of thereof" (Levine 2012, 117).

Polemics against idol worship was addressed in the doctrinal paintings of the Duran Jews just as in those of third-century Manichaeans. ${ }^{42}$ In their own respective ways, the leaders of these two communities instituted images for religious teaching in a world where statues of gods were actively worshipped. Therefore, it seems logical that they addressed the topic directly in the art itself they created. Manichaean documentary evidence about this is preserved in a Middle Persian transcript of an image-based sermon (M 219) given about the false belief of idol worship with the aid of a polemical image in Mani's Book of Pictures. This passage records how the elect began his teaching by pointing out the main motifs portrayed on one "painting" (nigār) that showed an idol temple, its priests, and its worshippers:

Direct eye and face (towards this and see) how it is depicted (....) here in front of you. On this nigār: idols, idol priests, altars, and their gods [...] depicted here, this is the temple of the idols, which they call 'The Dwelling of the Gods.' And corresponding to the name of the dwelling, there are many gods (there). Many are running about, (and) when you ask: 'Where (are you going)?' they say: 'To the Dwelling of the Gods. To offer reverence, love, gifts in front of them!' The idol priests raise their voices: 'Come forth to The Dwelling of the Gods!' However, inside The Dwelling of the Gods, here are no gods! The deceived do not realize that, because their spirits have been made intoxicated. But you [...]. (Asmussen 1975, 13)

The passage concludes by expressing what the Manichaeans found objectionable in idolatry. For them, it is the belief of the "deceived," whose "spirits have been made intoxicated," who falsely trust that one can "offer reverence, love, [and] gifts" by "com[ing] forth to The Dwelling of the Gods."

The Duran Jews' objection against idol worship is expressed vividly on the main wall of their synagogue (WB 4) through the portrayal of broken statues of gods in the Ark in the Land of the Philistines Panel (Fig. 3). The subject concerns a teaching also recorded in the first Book of Samuel about the history of the Ark of the Covenant in the Torah: the damage done by the Ark to the Temple of Dagon (I Sam. 5.1-5) on the right, and the Ark beginning its journey observed by the prince of the Philistines on the left, alluding to the misfortune and destruction

41 Jodi Magness $(2010,155)$ finds that, in addition to the "horizontal thematic connections" noted by Kraeling $(1956,168,225)$, there are also "vertical thematic connections" between the motifs of David being anointed (directly to the right of the Torah shrine) and David as the ruler of all Israel (above the Torah shrine). Magness concludes that the iconography of the synagogue documents eschatological and messianic expectations (Magness 2010, 164).

42 Religious historians of Late Antiquity dispute the claim that these murals hide polemics against Christianity, argued by Kessler (Weitzmann and Kessler 1990, 154-83). Although polemical literature was produced by the early church fathers during the second and third centuries, in Lee Levine's summary, "there is no way of knowing whether such polemics reached or effected the local Christian community, much less its Jewish counterpart," since there is no "unequivocal evidence that such issues were known in Dura or were of importance in Mesopotamia as far back as the early third century" (Levine 2012, 107). 


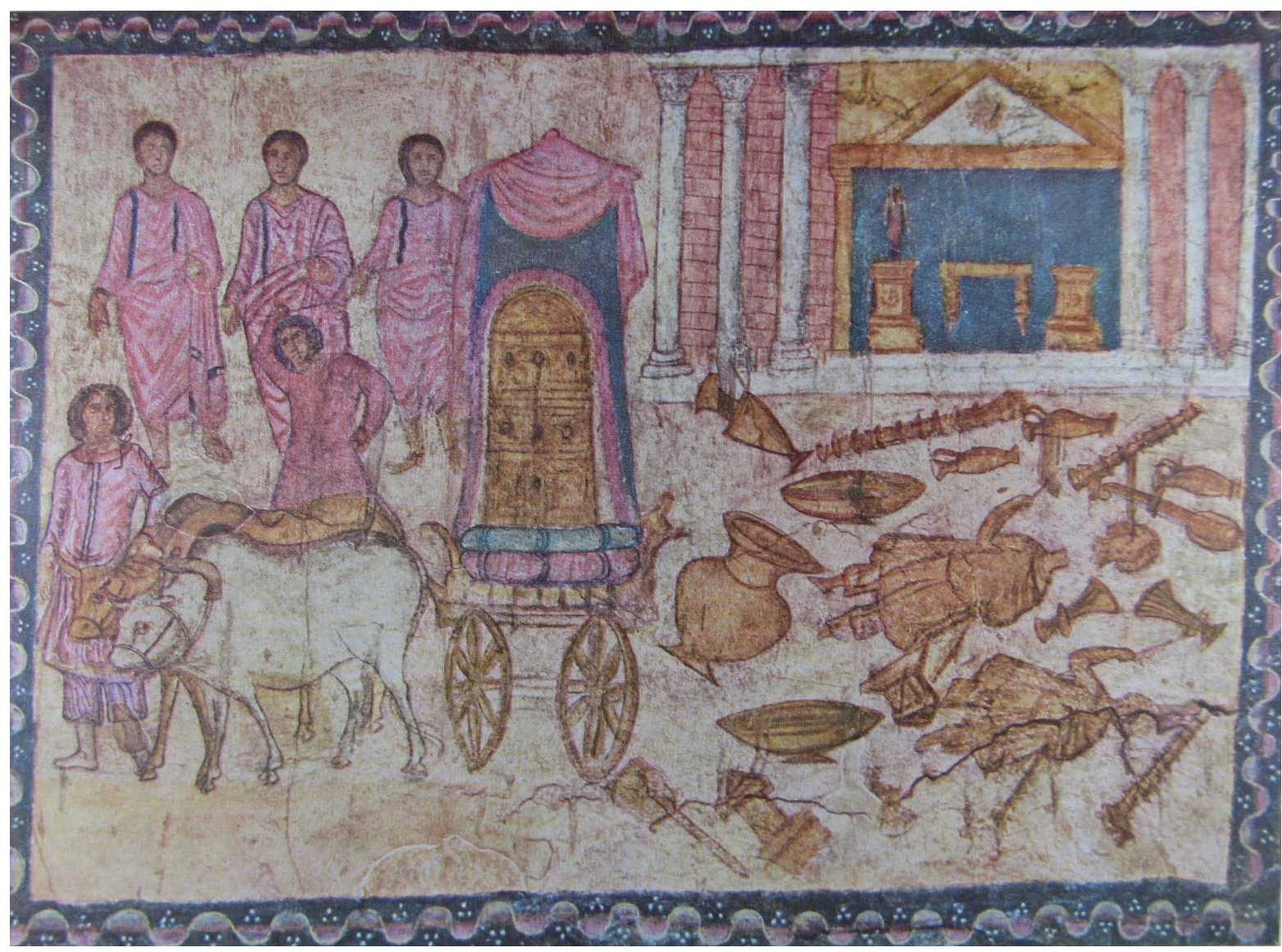

Figure 3 Panel conveying objection against idol worship after Kraeling (1956, Color Plates)

that the Ark caused on its way (I Sam 6.1-12) (Goodenough 1953, 10:74-80; Kraeling 1956, 99-105). The unambiguous polemical tone of the visual language of this panel corresponds to a teaching from Deuteronomy 12:3: "Tear down their altars, smash their pillars, put their sacred pots to the fire, and cut down the images of their gods, obliterating their name from the site." $" 43$

Likewise, the mural shows to the beholder the sculpted images of two deities (dressed in attire similar to Palmyran gods), smashed (one without a head and the other with a foot missing) and scattered among a large array of ritual implements littering the ground in front of an empty temple (Kraeling 1956, 101-3, with the inventory of objects in Fig. 30; see Goodenough 1953, 10:75). Compositional elements of this panel and its location impart a polemical tone. Not only is this panel placed furthest away from the Torah shrine on the west wall, but the chaotic rhythm of its destroyed idols is also blocked from the aedicula by the motifs of the frontally projected Ark (shown on a turning ox-cart as it is being driven to the left) and the massive walls protecting the Herodian Temple in the next panel on the left. Concerning the panel on its right depicting The Battle of Eben-ezer (NB 1) in the same register on the north wall, Kraeling entertains the idea that the portrayal of "the great victory of the God of Israel over the pagan gods" is "the appropriate counterpart of the disastrous defeated on the preceding panel" (Kraeling 1956, 103). Jaś Elsner sees a thematic counterbalance

$43 \quad$ Gutmann remarks: "In fact no other sacred ancient Near Eastern text is so concerned with images, high places, and their evil connotations as is Deuteronomy" $(1977,7)$. For a study that traces the evolution of the assumption of Jewish iconophobia, see Bland (2000, 1-11). 
between the "negative miracle" of the fall of the Philistine idol of Dagon and the "positive miracle" of the well shown in the Moses and the Wells of Elim Panel (WB 1), and notes a composition contrast between them, since in the well image, "the ritual objects of the Jews preside beneath the aedicula representing the Tabernacle; [while] in the Dagon scene, the cult implements of the Philistines are scattered with their gods." Many other panels portray sacrifice in contexts of polemical stories, but their visual language gives a "less aggressive commentary on local religion." Taken together, their analysis leads Elsner to conclude that polemics against pagan cults was prominently conveyed in the program of the synagogue (Elsner 2001, 282-83, 299; see Rajak 2013, 95-96).

\section{Didactic Function}

The doctrinal images of the Duran Jews and third-century Manichaeans fulfilled a variety of functions. While the images of both of these communities have associations with the divine and its worship, they also exhibit an educational character. Conveying doctrine by pictorial means is especially handy in multi-lingual missionary contexts possibly associated not only with the Manichaeans, but also with Jewish diaspora communities that increased converts to Judaism at this time. ${ }^{44}$ The didactic use of Mani's Book of Pictures forces us to reassess certain aspects of the physical remains of the Dura synagogue, including the interior design of its meeting hall, which signals the possibility that the Jews of Dura also involved their murals in teaching. This comparative approach allows us to see that both of these two distinctly different Mesopotamian communities (1) valued visual learning, (2) used their art for imagebased instruction, and (3) embedded educational tools into their images.

Literary sources specifically discuss the pedagogical value of images in third-century Mesopotamia by articulating the advantages of visual learning from both the instructor's and the pupil's point of view in connection with the Manichaean case. Mani gave a pedagogical rationale for why he made his Book of Pictures (Syr. Yuqnā), quoted in Ephrem's Prose Refutations: "Let the one who hears about them (the teachings) verbally also see them in the Yuqna (Syr. 'picture, image' < Gr. eikon), and the one who is unable to learn them from the word(s) learn them from the picture(s) (Syr. șurtā 'picture, image, illustration')" (Ephrem, Refutations 126.31-127.11; Reeves 1997, 262-63).

Speaking as a teacher, Mani distinguishes between auditory and visual learning in this passage. He states that those who were good auditory learners among his followers could easily understand and absorb what they heard, and to benefit those who learn more easily through visual means he made the Yuqnā. The efficacy of visual learning is conveyed from a pupil's point of view in Kephalaion 92, where an anonymous layman expressed the advantage of being exposed to images while learning about salvation, stressing the importance of learning to recognize events and deities in the afterlife based on their portrayal in the Book of Pictures (Copt. Hikōn): "For if we can see [. . .] the path of the catechumen, and know [. . .] so have we recognized him with knowledge. If we can also see him face to face in this Hikōn [. . .] in the sighting of him" (Kephalaion 92, 235.13-17; Gardner 1995, 241-42).

Although this record is fragmentary, the pupil's reasoning still comes through. He contends that seeing something "face to face in this Hikōn" facilitates learning. An analogous argument is preserved in Kephalaion 7 in connection with an image that helped the disciples learn about

44 Gutmann $(1992,504)$ agrees with Kessler's argument (Weitzmann and Kessler 1990, 188) that the murals of the Dura synagogue functioned as "a vehicle for religious propaganda, possibly to win converts," but firmly reject its anti-Christian claims. 
what happens after they die. With the aid of the painting under discussion, they were taught about a female deity (the Light Maiden, referred to here as "this Form of Light") who will come forth with three gift-gearing angels to greet them upon entering the afterlife. One again, the passage states that the deity will be familiar to the disciples, because she will look just as Mani ("the Apostle") depicted her in the Book of Pictures:

This Form of Light (is) the one who appears to everyone who will come out of his body-corresponding to the image of the Hikon of the Apostle (Mani)—with the three great glorious angels who have come with her ("this Form of Light"). One holds the prize in his hand. The second bears the garment of Light. The third is the one who holds the diadem and the wreath and the crown of Light. These are the three angels of Light, the ones who come with this Form of Light, and appear with her to the elect and catechumens. (Kephalaion 7, 36.12-20) ${ }^{45}$

Whether it was an icon (that is, a portrait of the Light Maiden with her three angels) or a narrative scene (that showed the deity with her three attendants approaching the righteous elect and catechumens), the depiction of these figures imparted key information with which a core soteriological subject was taught. By using such an image for teaching, Mani ensured that his disciples could visualize an event pertaining to a supernatural stage of their religious career.

The physical remains of the Dura synagogue demonstrate that visual communication was valued by its community. The Jews of this city invested considerable financial resources to create "the largest and most elaborate monument of decorative wall painting in the entire Roman Near East" (Kraeling 1956, 40), which constitutes "one of the most extensive figural painting cycles salvaged from antiquity" (Wharton 1995, 38). Indeed, they painted an extensive pictorial program onto the walls of their meeting hall that literally encircled them-three times, in three dense registers (see Fig. 4). They put eighteen panels on the west wall (if we count the three units-the Temple, the ritual implements, and the Sacrifice of Isaac-framed by the façade of the aedicula, as one panel). The other three walls are too damaged for an accurate count. Since the two side walls were shorter and the available surface of the back wall was reduced by the two doors, the total number of panels was likely around sixty (Kraeling 1956, Plans IX-XII). ${ }^{46}$

Yet the Mesopotamian Jewish context, in which this visual learning could have taken place, is poorly understood. Little to nothing is known about it. Gutmann stresses this point: "Let us state at the outset that we will not, or better, cannot hypothecate the precise kind of Judaism that flourished at Dura. No other similar synagogue has been found, no contemporary texts are available to explain the program, and the primary literary documents on hand are of such nature that they yield few clues to help us understand the many regional variations of the dominant and prevailing Judaism of that period" (Gutmann 1975, 217). ${ }^{47}$ Besides the archeological record of the Dura synagogue, there are no other third-century sources for Mesopotamian Judaism. ${ }^{48}$ Its assessment starts and ends with the nearly voiceless physical

45 For a new translation of this passage by Jason BeDuhn, see Gulácsi (2015, 32-33).

46 Gutmann estimates about fifty-eight (Gutmann 1984, 1314).

47 Jodi Magness draws attention to another poorly understood aspect of this Mesopotamian synagogue by arguing that the foundation deposit of finger bones found under the main door of its meeting hall (Kraeling 1956, 19) most likely played a Jewish apotropaic function (Magness 2010, 145-47).

48 Later traditions identify this period as the beginnings of the Rabbinic movement, which remained small and circumscribed to a few areas and spoke disapprovingly about non-Rabbinic Judaism practiced throughout Mesopotamia (see Neusner 1984, 122-77, 1999, 251-59, 274-87). 


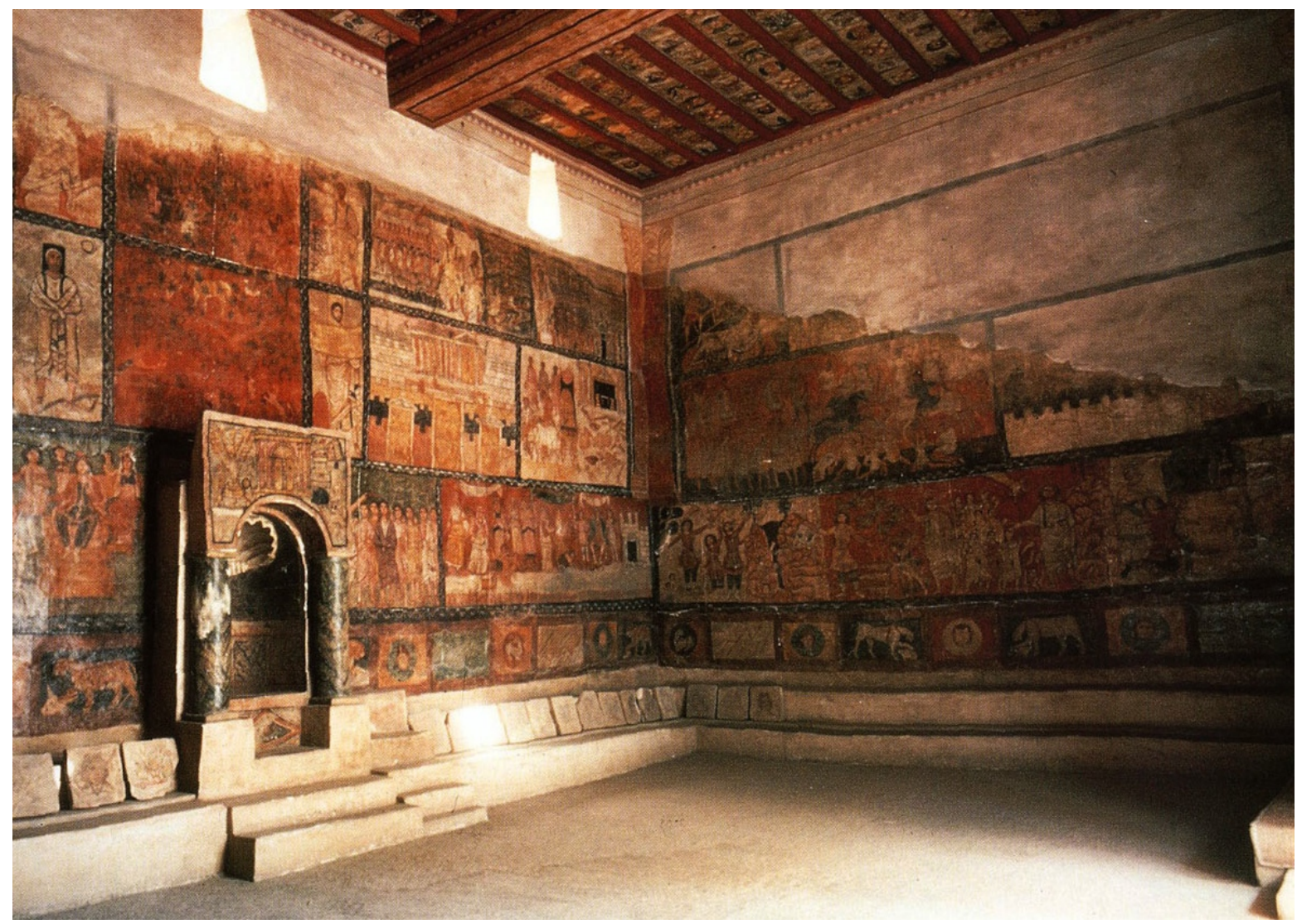

4a Reconstruction in the National Museum of Damascus (floor space: 13.7x7.7m, wall height: ca. 7m)

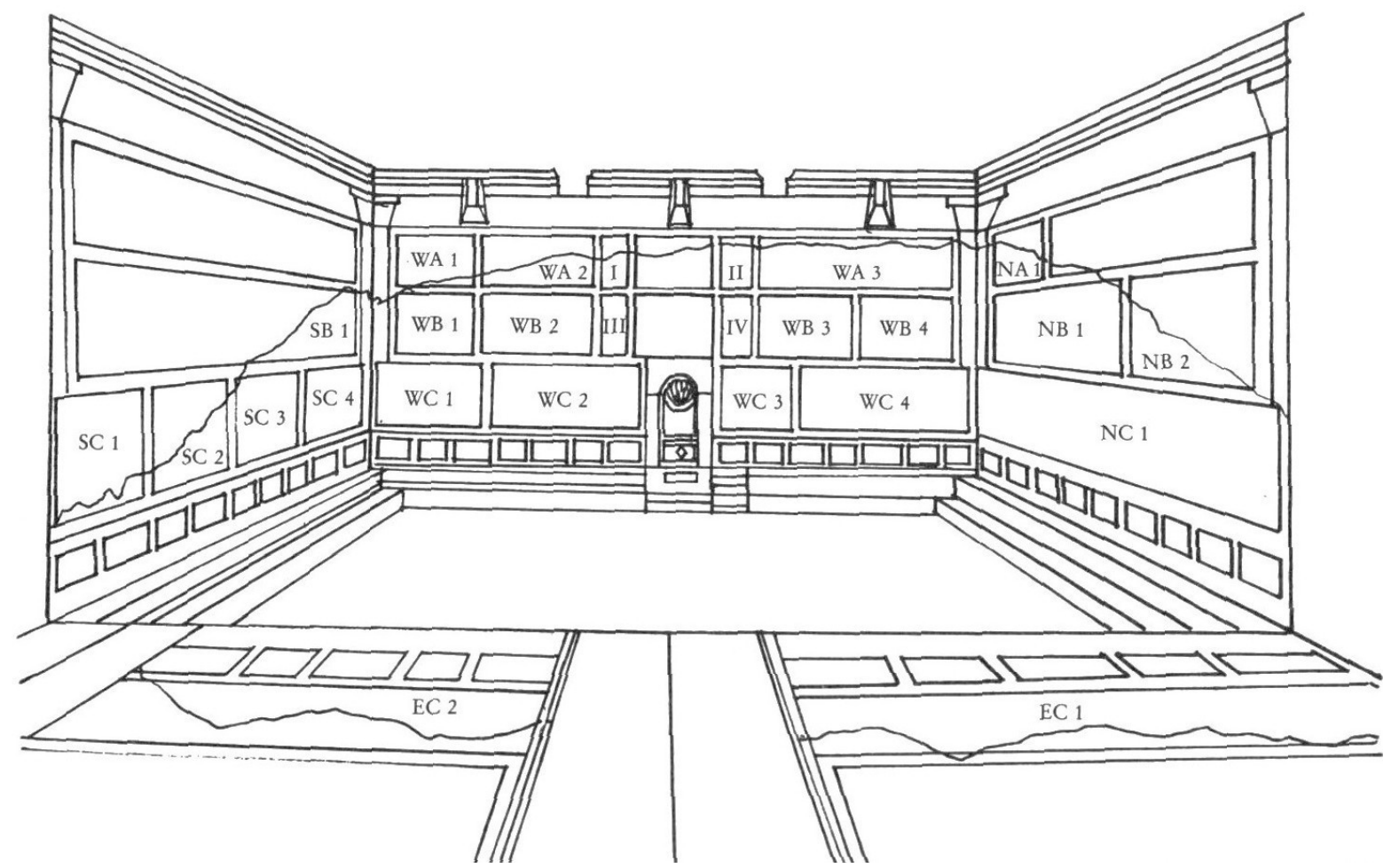

4b Distribution of panels based on Kraeling's codes for cardinal directions (N, S, E, W) and registers (A, B, C)

Figure 4 The meeting hall of the Dura synagogue, after Gutmann (1984, Plate I and Fig. 2) 
remains of a remarkable monument with a pictorial program that does not fit what is known about Judaism elsewhere at this time.

Jewish teaching has been traditionally associated with texts in the course of liturgy, that is, "public religious rituals within the context of the synagogue" (Levine 2000, 501). Levine writes: "There is no dimension more reflective of the growth and evolution of the synagogue in antiquity than liturgy. From contributing one of many activities in its early stages, the ritual component of the synagogue eventually became a dominant and definitive element" (Levine 2000, 501). ${ }^{49}$ This understanding, when applied to the Dura synagogue, has contributed to overlooking the didactic function of Jewish art in third-century Mesopotamia. As the Dura meeting hall is "the best-preserved Jewish liturgical space from late antiquity" (Fine 2005, 41), so is its pictorial program thought to be for teaching only as a component of liturgy-sermons given about the sacred texts. The didactic role of the art is folded into liturgy, since sermons have been imagined to belong exclusively to formal Jewish liturgy during the third century. Accordingly, it has been assumed that the panels of the synagogue were used in such a 'liturgical' context. Gutmann's hypothesizes that the "program at Dura probably was, as is the case in the later churches, the visual accompaniment of novel liturgical ceremonies, movements, and prayers recited or sung by the congregation" (1992, 504). Fine urges us to "imagine a preacher within the synagogue turning to the images and using them to homiletic effect-and to different effects, according to the content of his homily. The use of synagogue decorations as 'props' by homilists is known from rabbinic sources, as a similar process within somewhat later church contexts" (Fine 2005, 66-67). ${ }^{50}$ Another approach that has circumvented recognizing the educational significance of this painted synagogue is thinking about the doctrinal content of its paintings not as an essential religious tool, but as a decoration that celebrates ethno-religious identity. Levine explains: "while these other religious settings [the Mithraeum and the Church at Dura] were markedly focused on offering their congregants personal salvation, the synagogue's art vividly expressed the common ethnic and religious background of this Jewish community and of the Jewish people as a whole" $(2012,118)$. Either way, the Dura synagogue, as a place dominated by visual means of teaching and learning religion, is lost. Its interior design and pictorial program, however, express a reverence towards both text and image, signaling that this building fulfilled two religious functions-liturgical and didactic.

Sermons were noted to be the attraction of the ancient synagogue, fulfilling an integral didactic function for the community, sometimes independently of liturgy. The educational role of ancient sermons is noted by Charles Perrot, who distinguishes the different functions fulfilled by a "reader" (who, in Philo's words, "takes the books and reads" from them) versus a "teacher," "lecturer," or "communicator" (who, in Philo's words, "comes forward and explains anything that is not easy to understand"). While writing about the 'Covenanters' at Qumran, who were probably Essene-leaning, Perrot quotes from Philo:

They use these laws (those of the Pentateauch) to learn from at all times, but especially each seventh day, $[\ldots]$ they abstain from other work and betake themselves to the sacred places which they called synagogues. They are seated according to age in fixed places, the young below the old, holding themselves ready to listen

$49 \quad$ While writing about liturgy during the third century, Levine points out that in addition to a formalized prayer, liturgy had a "secondary focus," a Torah-reading ceremony, that consisted of reading the scripture and giving sermons/homilies about them on Sabbaths and holidays (Levine 2000, 523-56). 
with proper good manners. Then one of them takes the books and reads. Another comes forward and explains anything that is not easy to understand.... (Philo, Quod Omnis Probus Liber Sit 81-82; Perrot 1990, 152)

The words "comes forward" indicate stepping in front of the community to claim the attention of its members. Perrot argues that in some cases, the architecture of the synagogue itself confirms the paramount role of teaching in the synagogue: "Reading and teaching go hand in hand, as is mentioned in the inscription of Theodorus [...]. ${ }^{51}$ Teaching calls for reading and vice versa. May it not be said that unlike the proseuchae perhaps of the Diaspora, which appeared primarily as 'house of prayer', the Palestinian synagogues aimed originally at responding to a need for instruction?" (Perrot 1990, 150). Indeed, sermons played a vital role in the life of the community-they served to instruct all people in at least an elementary knowledge of the Torah as well as provide a forum of guidance in a variety of issues relevant to their lives. In his entry about ancient sermons for the Encyclopaedia Judaica, Joseph Heinemann emphasizes that the sages employed "at times daring methods of interpretation" to inspire and strengthen their community. Through their "bold use" of biblical material and "the application of ancient tradition to new circumstances," they "succeeded in keeping the Bible alive and meaningful for their own generations." The "entertainment value" was important in attracting people "in masses to hear sermons especially of well-known preachers (TJ, Hor. 3:7, 48b). They would come even from outlying villages, and would make special arrangements beforehand to permit them to exceed the 'Sabbath-limit' of 2000 cubits (Er. 3.5)" (Heinemann 2007, 467-68). Both Heinemann and Perrot call attention to the fact that the occasion of the sermons, that is, the days and times of their delivery, could vary. Some did not parallel the prescribed reading of the Torah and were independent of the regular rhythm of liturgy. Some could be "delivered on Friday nights (TJ, Sot. 1:4 16d), on Sabbath mornings after the reading of the scripture (Luke 4:16 ff.), or on Sabbath afternoons (Yal. Prov. 964). It appears that many sermons were given before the scriptural readings, serving as introductions to or preparation for the latter." ${ }^{2}$ Applying this understanding to the Dura synagogue raises the possibility that the narrative pictorial program of its meeting hall fulfilled a didactic function in a special sermon, separate from liturgy.

Archeological records document how ancient synagogues accommodated teaching -and in one case, arguably also image-based teaching-in relation to the community. ${ }^{53}$ In Perrot's word, "the layout of these buildings [...] may be said to 'petrify' as it were the seating arrangements of the disciples in a circle around their Master. These ancient synagogues were not oriented towards Jerusalem but towards the reader and lecturer in the middle of the building. And of course these masters taught on the Sabbath above all" (Perrot 1990, 150). At Dura, the act of reading from a scroll is documented by being depicted. In a wing panel of the reredos just above the right corner of the Torah shrine, the reader is portrayed stand-

51 To highlight these two equally important roles of the synagogue, Perrot's study starts with a quote from a dedicatory inscription: "Theodotus, son of Vettenus, priest and archisynagogue, son of an archisynagogue, and grandson of an archisynagogue, constructed the synagogue for the reading of the Law and the teaching of the commandments." It was found on the Ophel in 1914 among the remains of a synagogue that was built before 70 CE for Greek-speaking Jews and pilgrims in Jerusalem (Perrot 1990, 137).

52 Quotes above are from Heinemann $(2007,468)$. Perrot cites P.T. Sota 1:16b for Sabbath afternoon, and Lev. Rabba 9:9, p. 191 for Friday evening (Perrot 1990, 151).

53 Not all ancient synagogues were oriented towards Jerusalem, and about half of them have no Torah niche, either. Among the 27 surveyed conveniently a table by David Clausen (seven from Galilee, two from the Golan, twelve from Judea, and six from the diaspora), fourteen have no niches and only five have an aedicula (Clausen 2016, 170-71 and Tab.1). 
ing and holding his scroll at chest level (see Fig. 5). There is no evidence for a built-in bema platform to stand on, nor is the act of teaching portrayed on the walls. The space that the teacher and the community occupied, however, does survive (see Fig. 3). Built along the base of the four walls, the orientation of the community seated on the benches intersects in the middle of the floor. About the function and role of these benches, Rachel Hachlili writes: "it is clear that their placement directed the attention of those present to the focal point, in the center of the hall. The congregation sat there during the reading of the Torah, and during sessions of instructions, lectures, and political and social discussions, while the readers and lecturers either stood in the center or stood up in their place while leading, and the community members responded from their places. This layout of the hall functioned as a kind of theater in the round" (Hachlili 2013, 43), providing, in Levin's view, a "community-oriented framework [...] facilitating communal participation, be it for political, religious, or social purposes" (Levine 2000, 69). A total of three ancient synagogues are known for having benches along the four walls (Second Temple Gamla, Masada, and pre-renovation Dura) (Levine 2000, 131). ${ }^{54}$ Oriented in the manner described above, the seating marks either the center of these meeting halls or possibly one of the seats as the focal point of their communities' attention. Newly added in Stage 2, murals at Dura were fitted into an interior design set up already in Stage 1. Based on this fact, an argument can be made that the benches and the murals were employed in the course of the same event. In other words, the pictorial program was added to an activity already practiced in these meeting halls, fulfilling its function in conjunction with that activity, which not only relied on the benches encircling the center of the meeting hall, but also benefited from three registers of didactic murals depicting episodes of Jewish teaching. Focusing on one person who stood up to speak from the rings of benches built at the base of the four walls is not unlike focusing on one mural from the rings of registers painted on the four walls. The practical religious purpose of this feature begins making better sense when the meeting hall is viewed as a place of teaching and its narrative images as didactic tools-especially when considered in light of the third-century Mesopotamian evidence on specific didactic traits in art remarked about in connection with Mani's paintings.

Some elements of third-century Manichaean painting were specifically noted for their educational role. In his Prose Refutations, Ephrem remarks on how and why Mani used (1) labels and (2) contrasting aesthetic values. He explains that the positive and negative doctrinal roles of figures were captured via their appearances ("odious" vs. "lovely") in Mani's Book of Pictures. He also adds that this contrast was supposed to generate an emotional reaction in the viewer to "loathe" the "hideousness of Darkness" and "desire" the loveliness of the "sons of Light." Thus, the image conveyed visually an essential cognitive component of Mani's doctrine-its fundamental dualism. Ephrem writes:

He (Mani) labeled the odious (figures) 'sons of Darkness' in order to declare to his disciples the hideousness of Darkness, so that they might loathe it; and he labeled the lovely (figures) 'sons of Light' in order to declare to them its beauty so that they might desire it. (Ephrem, Refutations 126.31-127.11; Reeves 1997, 262-63)

This passage further notes that some figures were "labeled," that is, identified by an inscription. Similarly, a Middle Persian text (M 219) suggests that a building depicted in a polemical image was labeled as "The Dwelling of the Gods." The practice of using labels was still present

54 For a table tracking the interior design elements of ancient synagogues in Galilee, Judea, and the diaspora from between 50 BCE and late third century CE, see Clausen (2016, 170-71 and Tab.1). 
700 years later in Uygur editions of Mani's Book of Picture. ${ }^{55}$ The known fragments of these preserve (1) the practice of labeling figures together with many additional features, which were too archaic for their own time and place in East Central Asia during the ninth and tenth centuries. Likely, their use was preserved through generations of earlier editions of the Book of Picture, which ultimately lead back to third-century Mesopotamia, ${ }^{56}$ including (2) the horizontal scroll format, in which (3) decorative borders (often with wavy lines) frame the images and separate them from one another. ${ }^{57}$ These elements all facilitated a didactic application of art in the course of image-based sermons.

Considering the Dura synagogue in light of the above points brings to focus a possible educational role of Jewish painting in third-century Mesopotamia. Once the biblical scenes were added to its walls, the synagogue became a location where teaching with images and visual learning could take place. As a permanent display, the images were set up to facilitate these practices (see Fig. 5). They were defined with the viewer in mind. ${ }^{58}$ Painting them on a scale large enough to be visible from across the room allowed for three stacked registers. To assure an unobstructed view for all present, the lowest register (register C) was set at a height just above the heads of the people seated in the second row of benches-directly behind their backs was a decorative band. ${ }^{59}$ In this well-designed space, each panel functions as a cohesive pictorial unit separated from the adjacent units by ornamental borders with wavy lines (i.e., horizontal "register bands" and vertical "panel bands"). All figures are outlined in black and are shown against a monochromatic surface, often close to the foreground with little definition of depth to the picture space. A distinctly didactic element of the murals is the labeling of certain figures. Moses, Elijah, Mordecai, Ahasuerus, Esther, Samuel, and David are identified by inscriptions (Kraeling 1956, 269-72). Other figures of religious prominence and/or secular authority are shown beneath cloth canopies or seated in an Iranian fashion on a throne. Aided by these means, the panels at Dura were set up to function as visual tools for teaching.

The possibility that art could have played a leading rather than a subordinate role in a sermon has not been considered before in connection with the Dura synagogue. This principleattested in connection with Mani's Book of Pictures in third-century Mesopotamia-contrasts with Fine's interpretation about the homiletic function of narrative panels at Dura, which assumes that the images are secondary to the leading role played by scripture within the context

55 This fragment retains the word "Buddha" written vertically in the Sogdian script ("B-U-T") to identify Shakyamuni as one of the four primary prophets of Manichaeism [see Gulácsi (2015), p. 357, Figs. 5/2 and 6/5). Labels are written vertically in Uygur Manichaean art. Labels are also used to identify actual members of the living community in depiction rituals and in images of salvation seen on mortuary banners and in a frontispiece of a prayer book (Gulácsi 2005, 46-52; Gulácsi 2015, 265-70 and 335-345). No labels are attested on the remains of Chinese Manichaean art (twelfth to fifteenth centuries), suggesting that labels represent a West Asiatic element in Uygur Manichaean art, which was abandoned as the religion became Sinicized.

56 On Mani's commissioning his Book of Pictures from a local workshop, see notes 6-8 above.

57 Other such archaic, originally Syro-Mesopotamian characteristics of Uygur Book of Pictures fragments include (4) the use of a solid background, (5) keeping the figures in the foreground, (6) adding canopies to mark significance, (7) using the sun and moon symbols to flank the head of an important figure, (8) making God's hand reach down to the scene from above, (9) dressing figures in Iranian garments while (10) positioning them on a throne with knees spread, and (11) using hovering winged figures when needed. This is often not the case when art is meant to serve a ritual function, as seen, for example, in early Tibetan Buddhist temples surviving from Ladak and Guge, where the painting and sculpture are arranged to create a mandala of deities essential for the ritual performed in that space.

59 Kraeling $(1956,67)$ notes that although they look similar to one another, the three registers are actually uneven in height, fluctuating about $0.1 \mathrm{~m}$ from end to end. They measure: $1.1 \mathrm{~m}$ (A), $1.5 \mathrm{~m}(\mathrm{~B})$, and 1.3 $\mathrm{m}(\mathrm{C})$. Below register $\mathrm{C}$, the decorative band was approximately $0.7 \mathrm{~m}$ tall. 


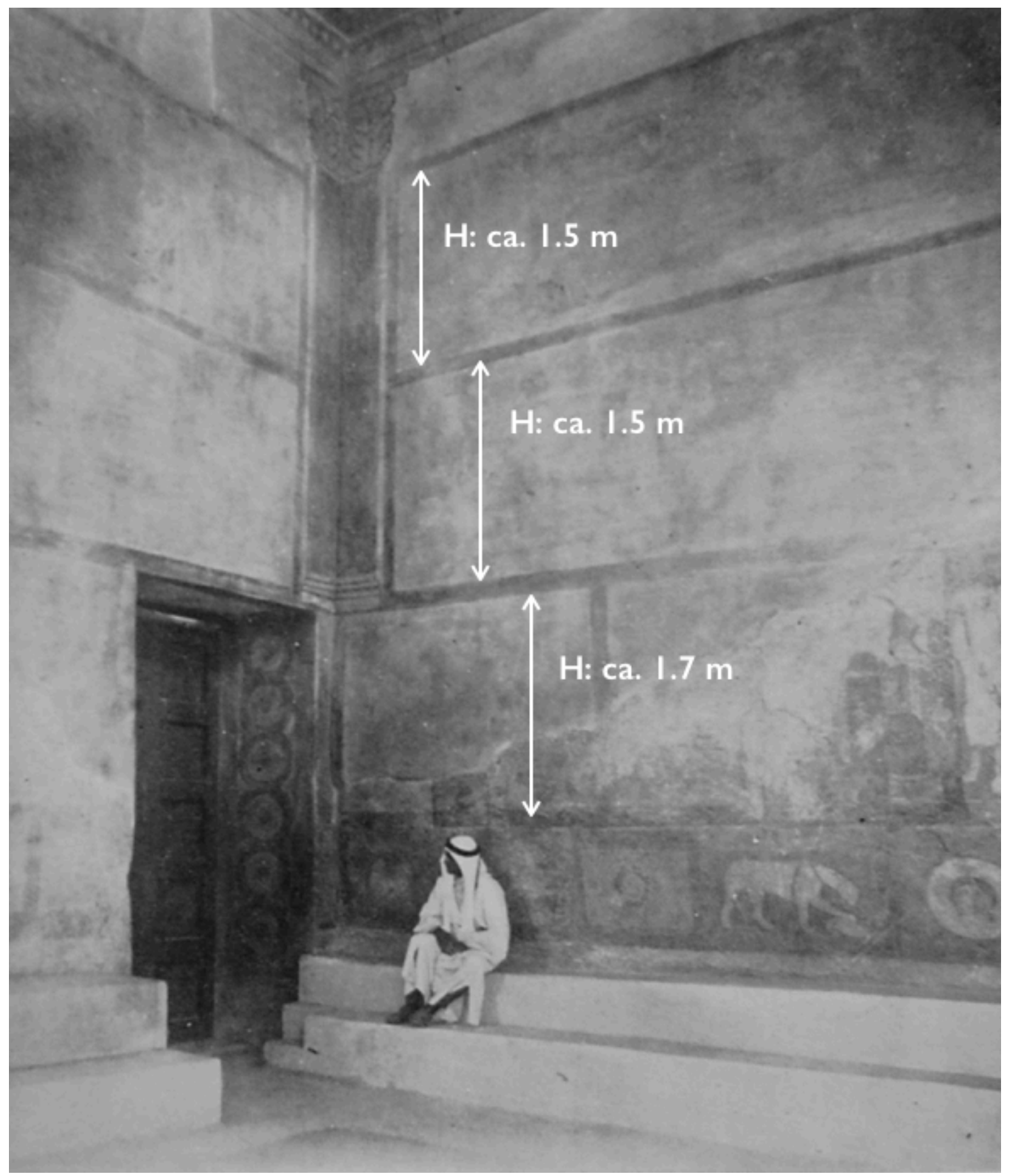

Figure 5 Scale of meeting hall (southeast corner) as reconstructed in the National Museum of Damascus (after Kraeling 1956, Plate XXV) 
of a sermon. Without elaborating, he imagines a preacher "turning to the images and using them to homiletic effect-and to different effects, according to the content of his homily" (see full quote above). If an image does not guide the instructions, however, what Fine describes would indeed have required turning around, that is, changing the direction of one's attention (maybe multiple times) during a homily. The preacher would have had to turn, just as would the entire community present. They all would have had to reorient themselves as the content of the sermon dictated, or else ignored the images. At any such sermon, some of the referenced images would have been out of the range of view of a significant portion of the audience, due to their seating position. In short, the imagined subordinate, supplementary role of the image in a text-based sermon is physically impractical, if not impossible. Effective didactic utilization of the pictorial program would require that a single panel (or a set of contiguous panels) served as a starting point of an image-based sermon. In addition to the Manichaean comparative evidence, therefore, the physical evidence of the Dura Synagogue itself demands a different explanation of how the images were used when the local Jewish community assembled there. Moreover, there is further Jewish data to support the claim that the narrative panels of the Dura synagogue played the leading role in planning and staging an image-based sermon by serving as the starting point of instruction. Jewish Studies scholarship about this may best be explored in connection with the oral context to teaching with images.

\section{Image-Based Oral Context}

The didactic paintings of the Duran Jews and third-century Manichaeans were used in an oral context. They were both designed to be part of communal teachings, functioning as props of speech in the context of live interpretations. Documentary evidence about this is especially strong in the Manichaean case, where a learned member of the community gave image-based instructions. While the archeological records of the synagogue are all but silent, certain iconographic features in its pictorial program signal that the Jews of Dura also involved their murals in live instructions. The data supplied by these two different communities about the purpose of their paintings reveals shared characteristics, including (1) the defining importance of an oral religious culture surrounding them, (2) evidence about live discussions of religious teaching preserved in them, (3) the need for a skilled teacher to sermonize with them, and that (4) they most likely played a leading role in image-based sermons.

Orality is firmly attested from third-century Mesopotamia in connection with Manichaean sermons-both with and without images. Mani's lay followers were urged to regularly listen to sermons in order to increase their knowledge (and so increase merit for their reincarnation). The utmost importance of this is reflected in the very designation of the laity. Laypeople are "catechumens" ( $<$ Gr. katēchoumenos 'one who is being taught orally'), that is, someone who is under instruction, or "auditors" ( < Lat. auditor 'hearer' or 'listener'), that is, someone who literally listens to religious instruction. Manichaean sermons given by the highest-ranking elects could be illustrated in third-century Mesopotamia only by the images of the Book of Pictures; but, starting from the fourth century, also by icons of Mani. ${ }^{60}$ The early Manichaeans

60 Icons of Mani (most likely panel paintings) are attested from Byzantine Levant, Umayyad Iraq, and preUygur Central Asia between the early fourth and early eighth centuries, including an illustrated sermon. Writing about 65 years after Mani's death, Eusebius of Caesarea (ca. 264-339 CE) mentions, in his Letter to Augusta Constantia, that he once saw "an icon (Gr. eikoni)" of Mani "escorted (or 'attended,' Gr. doruphoroumenon) by the Manichaeans." Early Islamic historiography discusses the defiling and destruction of icons of Mani in Baghdad and other cities of Iraq in 743-744 CE. A Manichaean primary source, the Compendium of the Doctrines and Styles of the Teaching of Mani, the Buddha of Light (short: Compendium), pre- 
even had a phrase for an image-based version of a live teaching, which survives in the Parthian language. (Part.) Ärdhang Wifrās translates as '(oral) sermon on the $\bar{A} r d h a n g$,' that is, on Mani's Book of Pictures. ${ }^{61}$ In its verbal form, wifrās- is a transitive verb with meanings such as "to teach something," "to show something" or "to proclaim something;" as a noun, it connotes "teaching," "instruction," "sermon," "homily," and "oral sermon" (Durkin-Meisterernst 2004, 352). ${ }^{62}$ Its connotation as a live teaching is especially relevant in connection with the Ârdhang, since the mention of a wifrās on the Ärdhang confirms the practice of giving an 'oral sermon' on the 'Book of Picture.' The language of the phrase signals an early origin, when Parthian was one of the primary Iranian tongues during the third and fourth centuries. ${ }^{63}$

In contrast, the oral context of the Jewish murals at Dura has been routinely overlooked in favor of a focus on their relationship to scripture. Most publications see these paintings merely as illustrations to the Hebrew Bible. "Deeply embedded in the scholarship on the synagogue," this approach is critiqued by Annabel Wharton in her Refiguring the Post Classical City. Writing about the Jewish pictorial program at Dura, Wharton notes that "scholars have been intent on identifying the text that explains the image" in order to find "unitary meaning" in art. Such "assumptions give priority to the literary text and repress alternative narratives offered by nonliterary texts and by the image itself. Indeed, the preoccupation with identifying explanatory texts seems to be a peculiarly scholarly form of policing meaning" (Wharton 1995, 43 and 45, respectively). Restricting meaning to the written word ignores the oral context of much of the religious discourse of the ancient world within which these paintings were made and used. Moreover, it yields a limited appreciation of their potential as visual sources of discussion independent of texts, leaving an important aspect of third-century Mesopotamian Judaism unexplored.

Evidence about the practical details of how pictorial art was employed for live instruction in third-century Mesopotamia is preserved in textual sources in connection with Mani's Book of Pictures. They attest that during one part of the teaching, art was a catalyst for dialogue and referenced by teacher and pupil alike. The disciples sat in front of it and stood up to ask questions. ${ }^{64}$ They were asked to look at an image, implying that it was pointed to: "Look, he (the righteous) is drawn in the Hikōn" (Kephalaion 92) and "direct eye and face (towards this and see) how it is depicted [....] here in front of you" (M 219). While looking, they were urged to "Listen ...!" (M 219) to the instructor, who used phrases such as "on this picture ..." (M 219) and "as it shows [...] so it shows" (M 4570). In one text, the question-answer part of an image-based instruction is recorded in its entirety, when an auditor inquires about the reincarnation of the laity (Kephalaion 92). He wants to know why, among the three possible destinies, Mani depicted only the two extremes in the Book of Pictures, the fate of the sinner

serves in Chinese translation from $731 \mathrm{CE}$ a sermon about an icon of Mani that was given by an anonymous, most likely Sogdian, high-ranking elect (see Gulácsi 2015, 117-18).

61 Werner Sundermann translates Ärdhang Wifrās as 'Sermon/discourse/commentary of/on the Ārdhang' and 'Treatise (or sermon) on the Ärdhang' and 'Oral Proclamation/teaching/recitation' as the original Parthian meaning of wifrās (Gulácsi 2017a).

62 In his study about the use of wifrās "teaching, sermon, etc.," Sundermann (1984) points to a Syriac pattern in Manichaean literature, with wifrās rendering Syr. mēmrā.

63 Its survival among the Turfan fragments as a Parthian text suggests a continued usage that stretched from the Parthian era through the Uygur era of Manichaean history until the early eleventh century in East Central Asia. By that time, Parthian was no longer a living language, but used only as a lingua sacra of the Manichaean Church.

64 Homilies 27: “... one who will sit in front of his Hikōn,” (Pedersen 2006, 27) and Kephalaion 92: "at ... one of the occasions, the catechumen [...] stood up. He said to our enlightener (Mani) [...]" (Gardner 1995, 241). 
(anyone who does not accept Mani's teachings) and the fate of the righteous elect, whereas he did not show the fate of the auditor/catechumen. Mani explains that the fate of the auditor is to be reborn in numerous bodies before his ultimate salvation. Therefore, to show the countless possible ways of rebirth in art is not practical:

Once again, at one of the occasions, the catechumen [...] stood up. He said to our enlightener [...]: 'Why have you marked every thing [... that exists], and what is provided to happen, in the great Hikōn? You have made clear in that great Hikōn; you have painted (Copt. zōgraphe < Gr. zōgraphein) the righteous one, how he shall be released and brought before the Judge and attain the land of light. You have also drawn the sinner, how he shall die. He shall be set before the Judge and tried [...] the dispenser of justice. And he is thrown into gehenna, where he shall wander for eternity. Now, both of these have been painted depicted by you in the great Hikōn; but why did you not paint the catechumen? How he shall be released from his body, and how he shall be brought before the Judge and reach the place ordained for him and [. . .] that he can rest in the place of rest forever. For if we can see [...] the path of the catechumen, and know [. . .] so have we recognized him with knowledge. If we can also see him face to face in the Hikōn] [. . .] in the sighting of him!'

Then speaks the enlightener to that catechumen: 'It is not possible to paint the catechumen in the Hikōn, because many [. . .] worlds and [. . .] before him from place to place [...] there are others existing [. . .] because to depict it, [...] since alone in a single place [. . .] you know [. . .] that the end of the catechumen [. . .] his path comes to be with the elect [. . .] of the elect. Look, he is drawn in the Hikōn [. . .] as the elect will [. . .] the catechumen will go [. . .] the path of the elect [...] will not go into the land of life [... of the] elect and the catechumen is a single one. However, it is not possible to paint the middle way of the purification of the catechumen, because he shall not be purified in a single place; nor cleansed and washed there.'

When that catechumen had heard these things, he was persuaded and [agreed] and kept his silence. (Kephalaion 92, 234.24-236.6; Gardner 1995, 241-42)

This passage mentions images employed as didactic tools, facilitating a discussion during an instruction on a soteriological topic. The remarks in the text about how the auditor "stood up" and addressed Mani "at one of the occasions" give the impression that we are joining in for the question-answer part of the teaching, most likely after Mani's introductory sermon had already been concluded.

The Dura synagogue also contains some clues indicating that live interpretations of Jewish teachings took place in its meeting hall. Seamlessly incorporated into the iconography of its murals, non-biblical motifs document popular knowledge familiar to the community. Jarl E. Fossum notes how a Hellenistic anthropology of body, spirit, and soul became integral to late ancient Jewish interpretations of biblical creation and revivification stories offered in both text and art. For a textual example, he points to Flavius Josephus, who renders Genesis 2:7 according to this trichotomy by inadvertently adding to it the concept of "spirit," while paraphrasing it as "God fashioned man by taking soil from earth, and sent spirit, and soul into him" (Judean Antiquities I. 34). For a Jewish visual record of this anthropology, Fossum 


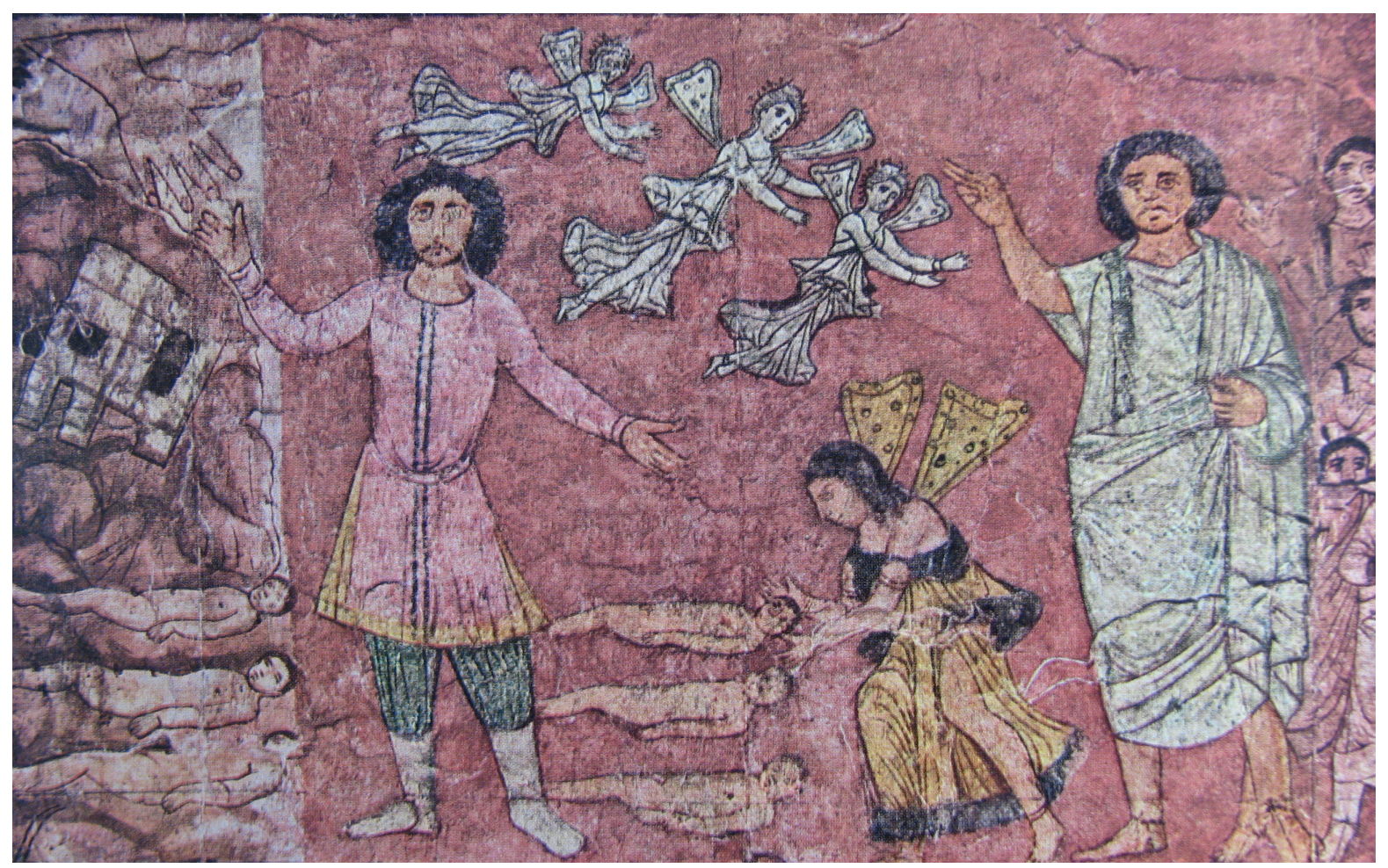

Figure 6 Panel reflecting Hellenistic anthropology (after Kraeling 1956, Color Plates)

points to the non-biblical exegesis of the Ezekiel panel at Dura (NC 1), where the raising of the dead shows three Psyches as symbols of spirits flying above the three dead bodies about to be resurrected (Fig. 6) (Fossum 1985, 210-11; cf. Schubert 1976, 213 ff.). Joseph Gutmann traces the presence of Jewish religious folklore on the walls of the synagogue by discussing five "novel features which depart from the biblical narrative" (Gutmann 1983). He calls them "aggadah-inspired illustrations" and explains how they do not correspond with the textual treatments of the same subjects in the Hebrew Bible. What they document visually from midthird-century Dura are alternative, apocryphal versions of stories attested from Jewish folklore as preserved in later Mesopotamian rabbinic literature from the fifth to seventh centuries CE. ${ }^{65}$ The correspondences between the later collection of legends and the non-biblical motifs of the Dura murals indicate the longevity of religious folklore shared within the two temporally different oral cultures they document from Jewish Mesopotamia.

Late ancient Jewish religious folklore has a significant presence in the Dura synagogue, impacting over one-third of the panels that are intact enough to be positively identified (Fig. 7). ${ }^{66}$ There are at least twelve such motifs, five of which were noted by Gutmann. Gutmann started surveying them with the Sacrifice of Isaac scene on the façade of the Torah shrine, where (1) the ram motif is not shown according to Genesis 22:13, "caught in the thicket by its horn," but rather quietly standing next to a tree awaiting its fate (Gutmann 1983, 92). He also mentioned the Samuel Anoints David panel (WC 3), where (2) David is shown with six brothers, and not seven, as in First Samuel 16:10 (Gutmann 1983, 96). The Infancy of Moses panel (WC 4) in itself contains five non-biblical motifs that accord with material in Ginzberg's

65 The stories were collected by Louis Ginzberg (Ginzberg 1937).

66 Listed from right to left, the fifteen identifiable narrative panels are NA 1 and WA 1 in the upper register, NB 1, WB 4, WB 2, WB 1 in the middle register, as well as the three-part panel NC 1 (counted here as three: NC 1 left, NC 1 middle, and NC 1 right) plus WC 4, WC 3, WC 2 WC1, SC 4 and SC 1 in the lower register. 
collection of Jewish legends about Moses. In accord with the latter, (3) the midwives are Moses' mother and sister, Jochebed and Miriam (Ginzberg 1937, 2:250-254), (4) the ark is covered with a "tiny canopy" (Ginzberg 1937, 2:265), (5) it is the pharaoh's daughter who retrieves the baby, (6) her arm is miraculously lengthened to reach the ark, and by so doing (7) her body is shown healed from leprosy (Ginzberg 1937, 2:266-267) ${ }^{67}$ In contrast, in Exodus 1:15-2:14, the midwives (Shiph'rah and Pu'ah) are not related to Moses, the ark has no cover, a servant retrieves the baby from the water, and there is neither mention of a lengthened arm nor reference to the body of the princess being healed from leprosy. The Moses and the Well panel (WB 1) contains a folkloric conflation of two separate biblical episodes: "the twelve springs of Elim" (Exodus 15:27) and "the miraculous well of Be'er" (Numbers 21:16). It is by bringing these stories together that the oral tradition produces the story of "Miriam's well" in the Jewish legends, from which the panel depicts three key elements: (8) the well that travels with the tribes and sets itself down in front of the Tabernacle at the campsites, (9) the tribal leaders that sing "the song of the well" in front of their tents, and (10) the well that responds to their songs by emitting a stream to each tent (Gutmann 1983, 98-99; Ginzberg 1937, 3:53). The story of Elijah and Priests of Ba'al, shown in two panels (SC 3 and SC 4), also contains non-biblical motifs that correspond with the Jewish legends. These are (11) Hiel, the priest of Ba'al hiding under the altar to light it secretly, and (12) the serpent sent by God to kill Hiel (Ginzberg 1937, 4:198), ${ }^{68}$ neither of which is found in the biblical text. These twelve elements are not what the community would have heard read out from scripture, which points to an independent sermonizing practice. Their presence further suggests that these paintings are visual references to midrash-like oral expositions.

Image-based sermons were conducted by leading elects among third-century Manichaeans, who relied on specialized teaching resources. These distinguished teachers were highly literate and learned, were involved with missionizing, and also handled the holy texts of their religion (the books of Mani's writings). During the third century, only the two uppermost positions in the hierarchy of the sacerdotal class are mentioned together with the Book of Pictures: (1) Mani and his successor, that is, the head of the Manichaean Church (Parth. sar, Lt. primate); and (2) Mani's own disciples, who belonged to the rank of 12 "Teachers" (Parth. $\bar{a} m \bar{o} \check{z} \bar{a} g$, Lt. maior). They are routinely noted to also have carried a written book of Mani while missionizing with the Book of Pictures. ${ }^{69}$ Verbal records of Mani's wisdom could offer a handy reference for an elect preparing for a sermon. This impression is given by a unique genre of early Manichaean literature developed to aid image-based sermons. Still remembering the words of sermons Mani conducted with images, the first generation of disciples wrote one of them down, most likely in Syriac, as if it were a transcript, including what questions were asked and how they were answered; this survives in Coptic translation (Kephalaion 92). Other transcripts of image-based sermons were written in Parthian (M 4570) and Middle Persian (M 219) (Gulácsi 2015, 152-53). In addition, a unique teachers' guide was composed in Parthian titled "(Oral) Sermon on the Book of Pictures," the Parthian Ärdhang Wifrās (discussed above). It is important to emphasize that none of this literature describes details of the art. They reference a corresponding image only as the starting point of the instruction. They document that the instruction is not about the image; it needs the image only as a tool for a live teach-

67 Gutmann also discusses the "nude princess" (Gutmann 1983, 93-94).

68 Gutmann also discusses the Hiel motif (Gutmann 1983, 96).

69 Kephalaion 151, Homilies 27, M 2, M 5596, and M 5815 (Gulácsi 2015, 108). 


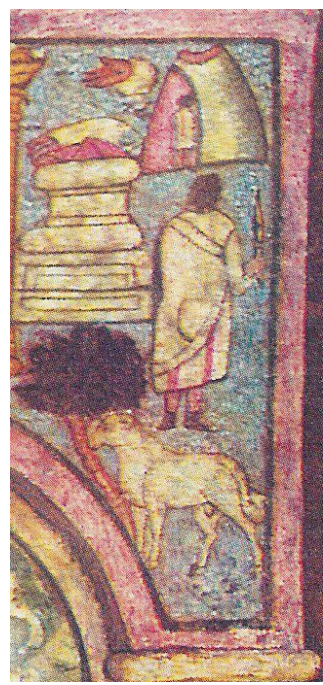

7a Sacrifice of Isaak

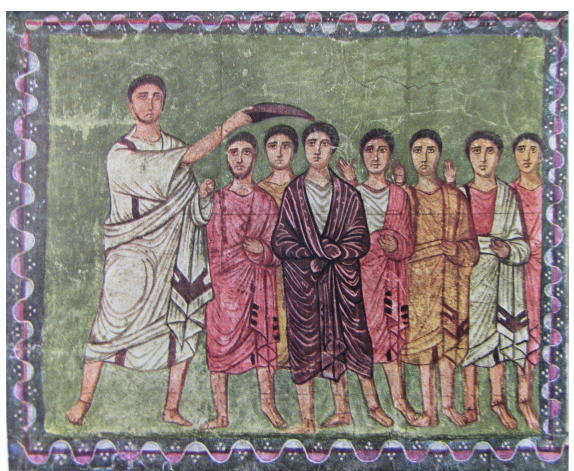

7b Samuel Anoints David panel (WC 3)

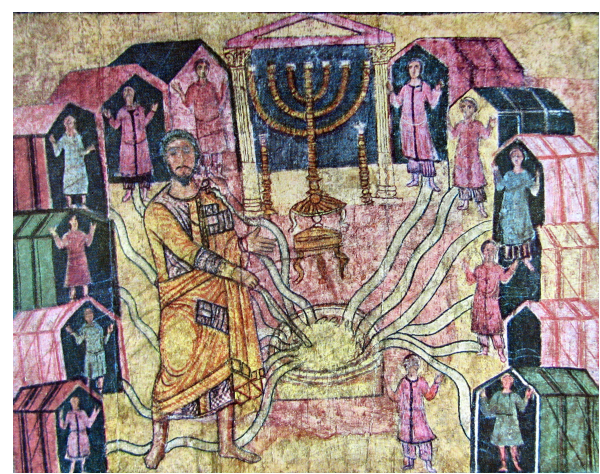

7c Moses and the Well panel (WB 1)

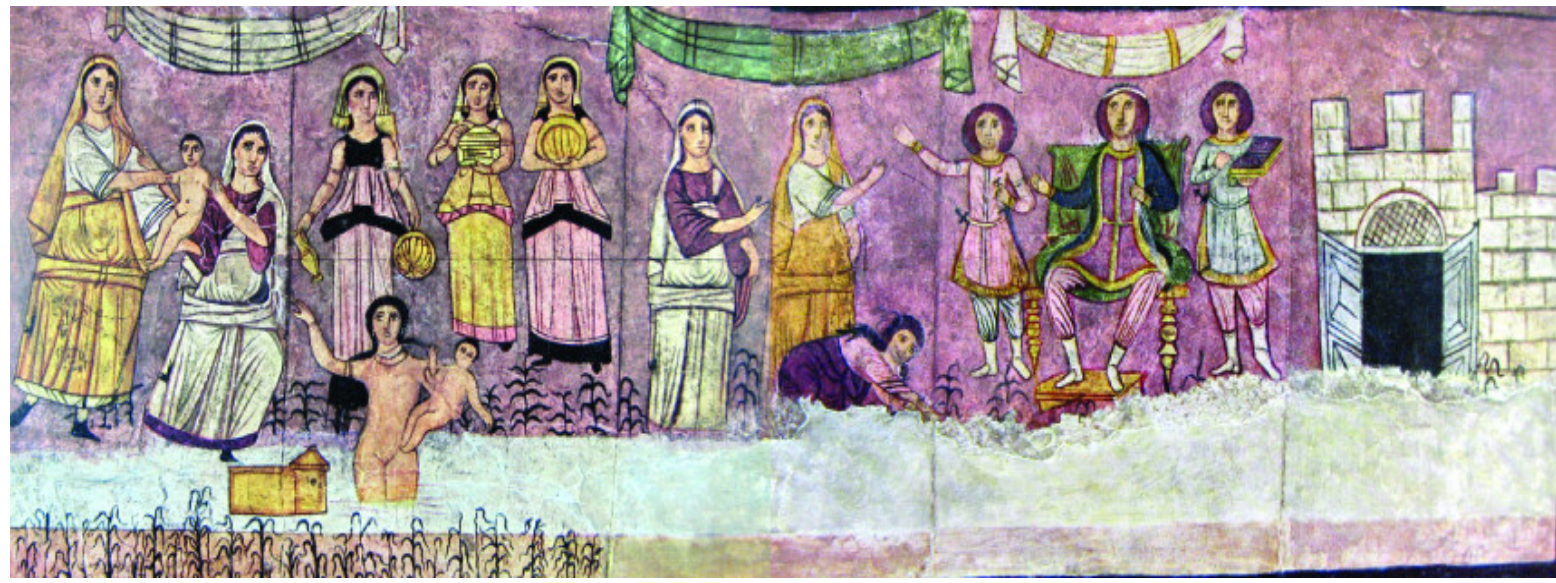

7d Infancy of Moses panel (WC 4)
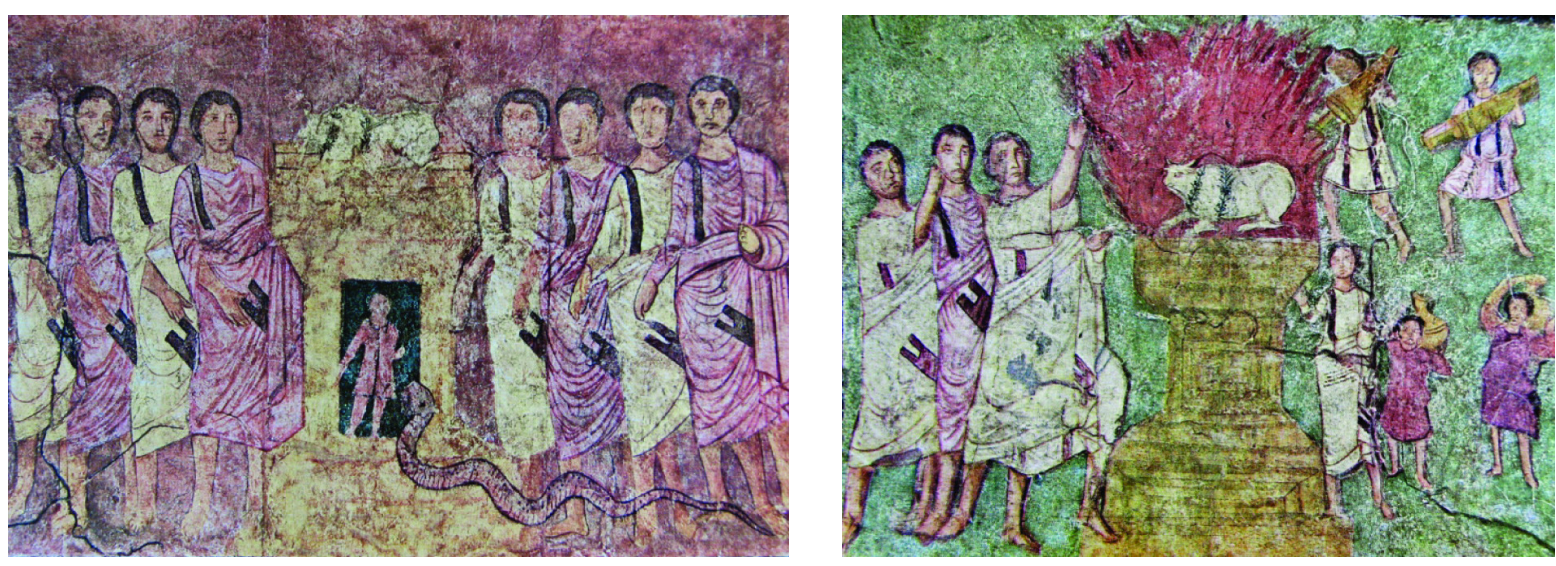

7e Elijah and Priests of Ba'al panels (SC 3 and SC 4)

Figure 7 Panels with motifs of Jewish religious folklore, after Kraeling (1956, Color Plates) 
ing about Manichaean doctrine. The elect who gave image-based sermons in third-century Mesopotamia had a more nuanced task among an already distinguished group of peers.

Being the 'house of the Sabbath' (Gr. sabbateion), ${ }^{70}$ ancient synagogues had a tradition of specialized sabbatical teaching. Perrot emphasizes a division of labor among specialists who had separate tasks on the Sabbath. The skills necessary for the reader of the Torah's Hebrew text and its Aramaic translator (distinct from the reader) ${ }^{71}$ were different from those of its commentator. While all of them had to be literate and learned in the Torah, rhetorical skills were also needed for the commentator. Perrot considers the challenges that small communities in Judea and Galilee must have faced for filling these roles: "contrary to the rich and important proseuchae or synagogues in Antioch or Alexandria, the buildings housing synagogues in Israel must have seemed meager and poor with no great architectural quality. But they were numerous, especially in Jerusalem and even in remote places like Nazareth. Under these circumstances one can guess how hard it was to find large numbers of readers and commentators at a time when schooling had barely begun to develop. It seems that one reader was enough for the Sabbath morning. This at any rate is what Philo gives us to understand, as do some later Jewish sources. If a priest was present, he could be asked first to take on the task, providing of course that he could read" (Perrot 1990, 154).

In contrast, the diaspora community at Dura was "at the height of its prosperity" during the middle of the third century (Kraeling 1956, 329-36). Its archaeological footprint leads Kraeling to conclude that it was sizable and well-off; its members owned Block L7 (see Fig. 2), which likely offered lodging for Jewish travelers (room 6); and it invested significant resources into the renovation and improvement of its property by adding to its meeting hall a large aedicula with a painted reredos for its "Torah chest" and masonry seating in Stage $1,{ }^{72}$ followed by a narrative pictorial program in Stage $2 .{ }^{73}$ This prosperity gives no reason to question the fact that the Dura synagogue could afford to have or host specialized teachersreaders, translators, and commentators-even before the narrative paintings were added to its meeting hall.

Image-based teaching seems to have had a place in this third-century Mesopotamian synagogue. Scholars of ancient Judaism agree that very little is known about homiletic practices prior to the time of the Talmud. They likewise agree that what survives as "literary midrashim" are collections and condensations of material from actual oral sermons, which could be used

70 Josephus, Ant. 16:164 (Perrot 1990, 146).

71 By "translator," two different functions could be implied: (1) Perrot discusses the "translator" who provided the reading in a different language: "During the reading of the Tora each verse, readout in Hebrew, could be translated into Aramaic, but by some other than the reader. In the case of the Prophets, the translator comes in after a group three verses. Only a few passages of the Tora are not to be translated: [...]. The Mishna wants the reading to be done from a leather scroll written in the Hebrew 'square script' (M. Megilla 2:2), not with the ancient Hebrew characters still known in the time of Bar Kokhba (died 135)" CE (Perrot 1990, 144). (2) Heinemann notes the "translator" (turgemen) whose task was "to broadcast the sermon in a loud voice-a service that sometimes was offered to the preacher as a token of respect (Heinemann 2007, 468).

72 Located on the façade of the aedicula below the base of the menorah, inscription No. 2 commemorates two donors (Uzzi, who "made" the aedicula, and Joseph, son of Abba, who "made" another object that no longer survives) in connection with the building of the Torah shrine (Kraeling 1956, 269. 332). The aedicula must have been added after the benches were in place, since its projection rests upon them. The Elder's seat, however, is built up against the side of the Torah shrine (Rostovtzeff et al. 1936, 323). Aramaic personal names, such as Uzzi and Abba, are also found among Mani's leading disciples, further indicating the geo-cultural relatedness of the Duran Jews and the third-century Manichaeans.

73 Seating capacity in Stage 2 doubles from 65 in Stage 1 (Kraeling 1956, 334), based on the length of the built-in benches but not the possible use of additional seating on mats and/or wooden benches (Levine 2012, 99). Rostovtzeff estimated it for about 90 people (Rostovtzeff et al. 1936, 324). 
in the creation of new ones (Heinemann 2007, 468-69; Perrot 1990, 158); in this respect, they resemble similar notes and outlines of sermon found in Manichaean texts. Without intending to claim anything about the contents of ancient sermons in light of medieval records, Perrot stresses that their character was likely similar to what is captured in later sources (Perrot 1990, 158). The literary midrashim presuppose a variety of approaches to the oral sermon. Heinemann explains that they could start either with a proem cited from scripture or with a halakhic question, which were followed by "the body of the sermon (whose structure is not clearly defined)," and many examples concluded with a "messianic" emphasis that some researchers claim to have detected in the Dura mural program. Nevertheless, he cautions that literary homilies "must not be confused with the actual live sermon as preached in the synagogue (in a variety of forms)" (Heinemann 2007, 469). Accordingly, when Wharton turns t the midrash literature in her study about the Dura synagogue, she is not in search of the meaning of specific scenes, but in search of analogous uses to explain what could happen to art in "an oral tradition intimate with both the sacred text and the narrative embellishment that so affectively integrated scripture with the daily life of the community."74 She argues that "instead of treating the frescos as illustrations of scripture or midrash, it is possible to read the frescos as prior to the written text," functioning in an oral context. Thus, the fortunate discovery of the extensive painting program at Dura opens to us a possibility undetectable from just the literary sources on Jewish sermons, namely, that an image itself could serve as the starting point of a sermon.

The claim that images could be the starting points of sermons given about larger doctrinal themes in third-century Mesopotamia is documented, in the Manichaean case, by the $\bar{A} r d-$ hang Wifrās. This text was not written as regular prose but rather as an abbreviated list of references to well-known stories suited for bringing up during instruction to help explain and contextualize the doctrine portrayed. It may be best compared to an outline that a teacher uses during teaching or notes that can be reviewed before oral instruction begins. One of its sections is a list of parables/stories. Each starts with the phrase "about/of," such as: "About a man who is granted much desire," or "About a ruler who [gave] a meal to the noblemen, ..." Another part contains a list of similes, each of which begins with the phrase "(it is) like."75 For examples, in one passage (M 35), the main theme is the "Great Fire" (also known as the "World Fire") that will consume the universe at the end of time. Instead of a simple exposition of this subject, the character of fire is referenced through a series of allegories, each of which is could be evoked while explaining the Great Fire shown in art:

The story of the Great Fire: Like the fire, with powerful wrath, swallows this world and enjoys it; Like this fire that is in this body, swallows the exterior fire that comes in fruit and food, and enjoys it; Like two brothers who found a treasure were lacerated by a pursuer, and they died; Like Ohya, Leviathan, and Raphael lacerated each other, and they vanished; Like

74 In Wharton's view, the pictorial program itself is a sermon: "Both midrash and fresco exemplify how the juxtaposition of narrative fragments produces a text. [...] Just as the midrash comment on fragments of scripture-letters of the alphabet, words, phrases, episodes-so, in the fresco details invite associations outside the narrative. [...] Just as lessons drawn by the rabbis and reported in the midrash manage an entire range of communal experience from the mundane to the celestial, so the frescos participate in the construction of reality by the rabbi for the viewer. The manipulation of images may have been as important then in the construction of authority in the synagogue as it is now in a public lecture on the history of art (Wharton 1995, 48, all quotes above are from this page). 
a lion-cub, a calf in a wood (or in a meadow), and a fox, who lacerated each another, [and they vanished or died]; So [the Great Fire swallows] both of the fires. ${ }^{76}$

The subjects of these references are clearly stated, mentioning elements of local Mesopotamian popular culture and Manichaean religious folklore that were readily comprehensible in the world of the intended audience at the time when its Parthian prose was written; but their nuanced meanings are not self-evident today. They were meant to provide an aide memoire to the teacher while preparing to give a sermon (wifrās) about the Great Fire with the help of an image in the Book of Pictures (Ārdhang). In other words, the Manichaeans' image-based sermon was about doctrine. The art used in it was a catalyst of discussion-teaching and learning as well as questions and answers.

Analogously, the panels in the meeting hall at Dura could have functioned as the starting point or a visual reference of a specialized sermon, but not its ultimate focus. The subject of such a sermon still addressed a teaching or some concern of the community, building on but not limited to an exposition of the artistic scene. Just as with a biblical quote, a sermon could start with art in this painted synagogue. Instead of jumping from detail to detail or scene to scene, the Manichaeans' Ärdhang Wifrās suggests the possibility that one panel (or a part of a panel) was employed as the basis for a sermon in the Dura synagogue. This practice would also have made use of all the benches, with the preacher standing either in the center of the room or in front of his seat, as Perrot and Hachlili explained. With a bit of advance planning, the design of the seating and the placement of the panels above head-level allowed for a comfortable view of each image for the community present.

The comparative textual evidence presented above on how third-century Manichaeans used their images in Mesopotamia compels us to consider the Dura synagogue as a place where image-based instruction took place. Moreover, it allows us to see for the first time a point of connection among Perrot's and Heinemann's views on the role of teaching in the ancient synagogue, as well as Wharton's view on the importance of orality and Levine's view on doctrinal themes for the pictorial program at Dura. Taken together, they suggest that its narrative murals could have brought an addition to the already existing didactic function of the ancient synagogue-one that, instead of being text-based and read, was image-based and oral in character.

\section{Conclusion}

Canonical texts have been the fundamental focus of what a religion is and where its teachings are to be found. Yet in late ancient Mesopotamia, even within the two most highly textual traditions, Judaism and Manichaeism, art was a practical tool in live teachings-providing that one rejects the notion that the Dura murals were only 'decoration' in a solely 'liturgical space.' Data suggests otherwise. The Jewish pictorial program at Dura had a doctrinal content and was well suited to fulfill a didactic function in an oral context, analogously to what another Mesopotamian religion did with its own art during the middle of the third century.

Evidence about the didactic function of Mesopotamian Jewish and Mesopotamian Manichaean art considered in this study fits a broader religious practice that spread across the trade routes of the Asian continent during Late Antiquity to become a pan-Asiatic 
phenomenon that Victor Mair has called "picture recitation" or "teaching with images."77 Although Manichaean analogies to Duran Jewish art have not been explored before, ${ }^{78}$ the foundations of this study are akin to previous scholarship about orality in ancient Judaism ${ }^{79}$ and the Iranian ("eastern"/"oriental") cultural elements in the pictorial program of the synagogue. ${ }^{80}$ To address the larger question of how Mani and the Jews of Dura were part of a broader presence of teaching with images in West Asia will require future comparative studies with a focus on materiality of religion and a scope that extends to analogous evidence from other religions (Mandaeism, Armenian Christianity, Sogdian Zoroastrianism, and Kushan Buddhism) that were active across the Iranian cultural region during Late Antiquity. Nevertheless, the narrower scope of this study serves to demonstrate for the first time that the Dura synagogue belongs to this larger regional phenomenon of religious artistic practice, and in particular has close affinities to a contemporaneous didactic use of art among a neighboring (and rival) religious community formed around Mani and the first generation of his disciples during the middle of the third century.

\section{References}

Asmussen, Jes Peter. 1975. Manichaean Literature: Representative Texts Chiefly from Middle Persian and Parthian Writings. Delmar, NY: Scholars' Facsimiles \& Reprints.

Ball, Warwick. 2000. Rome in the East: The Transformation of an Empire. London, UK: Routledge.

Bland, Kalman P. 2000. The Artless Jew: Medieval and Modern Affirmations and Denials of the Visual. Princeton, NJ: Princeton Univ. Press.

Boyce, Mary, ed. 1975. A Reader in Manichaean Middle Persian, and Parthian: Texts with Notes. Vol. 9. Acta Iranica. Leiden: Diffusion E.J. Brill.

Bregman, Marc. 1982. "The Darshan: Preacher and Teacher of Talmudic Times." The Melton Journal 14: 3.19.26.

Clausen, David Christian. 2016. The Upper Room and Tomb of David: The History, Art, and Archaeology of the Cenacle on Mount Zion. Jefferson, NC: McFarland \& Company.

Deeg, M., and I. Gardner. 2009. "Indian Influence on Mani Reconsidered: The Case of Jainism." International Journal of Jaina Studies 5 (2): 1-30.

Durkin-Meisterernst, Desmond, ed. 2004. Dictionary of Manichaean Texts. Vol. 3.1. Corpus Fontium Manichaeorum Subsidia. Turnhout: Brepols.

Elsner, Jaś. 2001. "Cultural Resistance and the Visual Image: The Case of Dura Europos." Classical Philology 96 (3): 269-304. http://www.jstor.org/stable/1215434.

Fine, Steven. 2005. "Liturgy and the Art of the Dura Europos Synagogue." In Liturgy in the Life of the Synagogue: Studies in the History of Jewish Prayer, edited by Ruth Langer and Steven Fine, 35-66. Duke Judaic Studies Series 2. Winona Lake, IN: Eisenbrauns.

77 Victor Mair does not discuss Dura and third-century Mesopotamia, but mentions the Manichaean archeological remains that survive from their Uygur era (Mair 1988, 50-53).

78 While the Manichaean analogies of Duran Jewish art have not been explored before, preliminary remarks to this study were published in (Gulácsi and BeDuhn 2011-2015; Gulácsi 2015).

79 For studies on orality in Ancient Judaism, I rely on Susan Niditch (1997) and the only study that considers the murals of the Dura synagogue in context of living sermons by Annabel Wharton (1995).

80 The Iranian (Parthian and Sasanian) elements of Duran Jewish art have been noted since the 1930s in the garments and the regal sitting position used for distinguishing men of secular authority. In addition, Dalia Tawil (Tawil 1979) showed the visual jargon of Iranian imperial art in the investiture motif and triumph motif of the Mordechai and Esther panel (WC 2). 
Flesher, Paul V. M. 1995. "Rereading the Reredos: David, Orpheus, and Messianism in the Dura Europos Synagogue." In Ancient Synagogues: Historical Analysis and Archaeological Discovery, edited by Dan Urman and Paul V. M. Flesher, 346-66. Studia Post-Biblica 47,2. Leiden: Brill.

Fossum, Jarl E. 1985. The Name of God and the Angel of the Lord: Samaritan and Jewish Concepts of Intermediation and the Origin of Gnosticism. Wissenschaftliche Untersuchungen Zum Neuen Testament 36. Tübingen: Mohr.

Gardner, Iain, ed. 1995. The Kephalaia of the Teacher: The Edited Coptic Manichaean Texts in Translation with Commentary. Nag Hammadi and Manichaean Studies 37. Leiden: Brill.

. 2005. "Some Comments on Mani and Indian Religions According to the Coptic Kephalaia." In New Perspectives in Manichaean Studies, edited by Alois van Tongerloo and Luigi Cirillo, 123-35. Manichaean Studies 5. Turnhout, Belgium: Brepols.

Ginzberg, Louis. 1937. The Legends of the Jews. Translated by Henrietta Szold and Paul Radin. Philadelphia: Jewish Publication Society of America.

Goodenough, Erwin J. 1953. Jewish Symbols in the Greco-Roman Period. New York: Pantheon Books.

Gulácsi, Zsuzsanna. 2008. "The Life of Jesus According to the Diatessaron in Early Manichaean Art and Text." Bulletin of the Asia Institute 22: 143-69.

- 2010. "The Prophet's Seal: A Contextualized Look at the Crystal Sealstone of Mani (216-276 C.E.) in the Bibliothèque Nationale de France." Bulletin of the Asia Institute 24: 161-85. http://www.jstor.org/stable/43896125.

- 2015. Mani's Pictures: The Didactic Images of the Manichaeans from Sasanian Mesopotamia to Uygur Central Asia and Tang-Ming China. Nag Hammadi and Manichaean Studies 90. Leiden: Brill.

. 2017a. "A Parthian Exposition on Mani's Collection of Didactic Paintings: A Contextualized Study of a Fragmentary Ārdhang Wifrās Bifolio (M 8255) in the Turfanforschung of the BBAW, Berlin.” In Zur lichten Heimat: Studien zu Manichäismus, Iranistik und Zentralasienkunde im Gedenken an Werner Sundermann, edited by Team „Turfanforschung“, 195-210. Iranica 25. Wiesbaden: Harrassowitz Verlag.

- 2017b. "Symbols of Liberation: The Salvation-Seeking Souls, the Primary Prophets, and the Light Mind in Manichaean Didactic Painting." In Gnose et Manichéisme: Entre Les Oasis d'Égypte et La Route de La Soie: Hommage à Jean-Daniel Dubois, edited by Anna Van den Kerchove, Luciana Gabriela Soares Santoprete, Jean-Daniel Dubois, and École Pratique des Hautes Etudes, 241-59. volume 176 13. Turnhout: Brepols.

— 2018. "Visual Catechism in Third-Century Mesopotamia: Reassessing the Pictorial Program of the Dura-Europos Synagogue in Light of Mani's Book of Pictures." Journal of Ancient Judaism 9 (2): 201-29. https://doi.org/10.13109/jaju.2018.9.2.201.

Gulácsi, Zsuzsanna, and Jason BeDuhn. 2011-2015. "Picturing Mani’s Cosmology: An Analysis of Doctrinal Iconography on a Manichaean Hanging Scroll from 13th/14th-Century Southern China." Bulletin of the Asia Institute 25: 55-105.

Gutmann, Joseph. 1975. "Programmatic Painting in the Dura Synagogue." In The Synagogue: Studies in Origins, Archaeology, and Architecture, edited by Joseph Gutmann, 210-32. The Library of Biblical Studies. New York: Ktav Pub. House.

- 1977. "Deuteronomy: Religious Reformation or Iconoclastic Revolution?" In The Image and the Word: Confrontations in Judaism, Christianity and Islam, edited by Joseph 
Gutmann, 5-25. Religion and the Arts 4. Missoula, MT: Scholars Press for the American Academy of Religion.

— 1983. "The Illustrated Midrash in the Dura Synagogue Paintings: A New Dimension for the Study of Judaism." Proceedings of the American Academy for Jewish Research 50: 91-104. https://books.google.de/books?id= eo3jAAAAMAAJ.

—. 1984. "Early Synagogue and Jewish Catacomb Art and Its Relation to Christian Art." In Aufstieg und Niedergang der römischen Welt: Geschichte und Kultur Roms im Spiegel der neueren Forschung, edited by Wolfgang Haase, 1313-42. Berlin: Walter de Gruyter.

- 1992. "Review of the Frescoes of the Dura Synagogue and Christian Art, by Kurt Weitzmann and Herbert L. Kessler." Speculum 67 (2): 502-4. https://doi.org/10.2307/ 2864459.

Hachlili, Rachel. 1976. "The Niche and the Ark in Ancient Synagogues." Bulletin of the American Schools of Oriental Research 223: 43-53. https://doi.org/10.2307/1356719.

- 1998. Ancient Jewish Art and Archaeology in the Diaspora. Leiden: Brill.

. 2013. Ancient Synagogues_Archaeology and Art: New Discoveries and Current Research. Leiden: Brill.

Heinemann, Joseph. 2007. "Preaching: In the Talmudic Period." In Encyclopaedia Judaica, edited by Fred Skolnik and Michael Berenbaum, 16:467-70. Detroit: Macmillan Reference USA in association with the Keter Pub. House.

Henning, W. B. 1943. "The Book of the Giants." Bulletin of the School of Oriental and African Studies, University of London 11 (1): 52-74. http://www.jstor.org/stable/609205.

Jensen, Robin M. 1999. "The Dura Europos: Synagogue, Early Christian Art, and Religious Life in Dura Europos." In Jews, Christians, and Polytheists in the Ancient Synagogue: Cultural Interaction During the Greco-Roman Period, edited by Steven Fine, 174-89. Baltimore Studies in the History of Judaism. London, UK: Routledge.

Jones, F. Stanley. 2010. "Some Things Mani Learned from Jains." In Sur les pas des Araméens chrétiens: mélanges offerts à Alain Desreumaux, edited by Françoise Briquel-Chatonnet and Alain Desreumaux, 383-98. Cahiers d'études syriaques 1. Paris: Geuthner.

Klimkeit, Hans-Joachim, ed. 1993. Gnosis on the Silk Road: Gnostic Texts from Central Asia. San Francisco, CA: Harper.

Kraeling, Carl Hermann. 1935. A Greek Fragment of Tatians's Diatessaron from Dura. London, UK: Christophers.

- 1956. The Synagogue: Excavations at Dura-Europos, Final Report VIII, Part 1. New Haven CT: Yale University Press.

Kuttner, Ann. 2015. "Trajan's Column." Grove Art Online. http://www.oxfordartonline.com/ subscriber/article/grove/art/T2288061.

Le Strange, Guy. 1930. The Lands of the Eastern Caliphate: Mesopotamia, Persia, and Central Asia from the Moslem Conquest to the Time of Timur. Cambridge, MA: Cambridge University Press.

Levi, Annalina, and Mario Levi. 1978. La Tabula Peutingeriana. Bologna: Edizioni Edison.

Levine, Lee I. 2000. The Ancient Synagogue: The First Thousand Years. New Haven, CT: Yale University Press.

- 2012. Visual Judaism in Late Antiquity: Historical Contexts of Jewish Art. New Haven, CT: Yale University Press.

Lieu, Samuel N. C. 1992. Manichaeism in the Later Roman Empire and Medieval China. Wissenschaftliche Untersuchungen Zum Neuen Testament 63. Tübingen: J.C.B. Mohr. 
Lowden, John. 1992. The Octateuchs: A Study in Byzantine Manuscript Illustration. University Park, PA: Pennsylvania State University Press.

Magness, Jodi. 2010. "Third Century Jews and Judaism at Beth Shearim and Dura Europos." In Religious Diversity in Late Antiquity, edited by David M. Gwynn, Susanne Bangert, and Luke Lavan, 135-66. Leiden: Brill.

Mair, Victor H. 1988. Painting and Performance: Chinese Picture Recitation and Its Indian Genesis. Honolulu: University of Hawaii Press.

Morony, Michael. 1989. "BĒT LAPAṬ." In Encyclopaedia Iranica. New York: Ehsan Yarshater Center for Iranian Studies, Columbia University. http://www.iranicaonline.org/articles /bet-lapat.

Nagel, Peter. 1981. "Zographein und das 'Bild' des Mani in den koptisch-manichäischen Texten." In Eikon und Logos, edited by Hermann Goltz and Konrad Onasch, 199-238. Halle: Martin-Luther-Universität Halle-Wittenberg.

Neusner, Jacob. 1984. A History of the Jews in Babylonia: Part 1: The Parthian Period. Brown Judaic Studies 62. Chico, CA: Scholars Press.

- 1999. A History of the Jews in Babylonia: Part 2: The Early Sasanian Period. Atlanta, GA: Schoolars Press.

Niditch, Susan. 1997. Oral World and Written Word: Orality and Literacy in Ancient Israel. Library of Ancient Israel. London: SPCK.

Pedersen, Nils. 1993. Manikceerne I Agypten. Aarhus: Aarhus Universitetsforlag. https://doi. org/10.7146/rt.v0i22.5322.

Pedersen, Nils Arne, ed. 2006. Manichaean Homilies: With a Number of Hitherto Unpublished Fragments. Corpus fontium Manichaeorum 2. Turnhout: Brepols.

Perkins, Ann Louise. 1973. The Art of Dura-Europos. Oxford: Clarendon Press.

Perrot, Charles. 1990. "The Reading of the Bible in the Ancient Synagogue." In Mikra: Text, Translation, Reading, and Interpretation of the Hebrew Bible in Ancient Judaism and Early Christianity, edited by M. J. Mulder and Harry Sysling, 137-59. Assen: Van Gorcum, Fortress Press.

Petersen, William L. 1990. "Tatian's Diatessaron.” In Ancient Christian Gospels: Their History and Development, edited by Helmut Koester, 403-30. London, UK: SCM Press.

Quispel, Gilles. 1993. "A Diatessaron Reading in a Latin Manichean Codex.” Vigiliae Christianae 47 (4): 374-78. https://doi.org/10.1163/157007293X00240.

Rajak, Tessa. 2013. "The Synagogue Paintings of Dura-Europos: Triumphalism and Competition." In The Image and Its Prohibition in Jewish Antiquity, edited by Sarah Judith Katharine Pearce, 89-109. Journal of Jewish Studies Supplement Series 2. Oxford: Journal of Jewish Studies.

Reeves, John C. 1997. "Manichaean Citations from the Prose Refutations of Ephrem." In Emerging from Darkness: Studies in the Recovery of Manichaean Sources, edited by Paul Allan Mirecki and Jason BeDuhn, 217-88. Nag Hammadi and Manichaean Studies 43. Leiden: Brill.

- 2011. Prolegomena to a History of Islamicate Manichaeism. London, UK: Equinox Publishing. http://site.ebrary.com/id/10696997.

Rostovtzeff, M. I., A. R. Bellinger, C. Hopkins, and C. B. Welles, eds. 1936. The Excavations at Dura-Europos Conducted by Yale University and the French Academy of Inscriptions and Letters: Preliminary Report of the Sixth Season of Work, October, 1932-March, 1933. New Haven: Yale University Press. 
Schubert, Ursula. 1976. "Die Erschaffung Adams in einer spanischen Haggadah-Handschrift des 14. Jahrhunderts (Br. Mus. Or. 2884) und ihre spätantike jüdische Bildvorlage." Kairos 18: 213-17.

Sundermann, Werner. 1968. "Christliche Evangelientexte in der Überlieferung der iranischmanichäischen Literatur." Mitteilungen des Instituts für Orientforschung 14 (3): 386-405.

— 1984. "Die Prosaliteratur der iranischen Manichäer." In Middle Iranian Studies: Proceedings of the International Symposium organized by the Katholieke Universiteit Leuven from the 17th to the 20th of May 1982, edited by Wojciech Skalmowski, Alois van Tongerloo, and Katholieke Universiteit te Leuven, 227-41. Orientalia Lovaniensia Analecta 16. Leuven: Peeters.

— 2005. "Was the Ārdhang Mani's Picture-Book?" In Il Manicheismo : Nuove Prospettive Della Ricerca : Quinto Congresso Internazionale Di Studi Sul Manicheismo, Atti : Dipartimento Di Studi Asiatici, Università Degli Studi Di Napoli “L'Orientale”, Napoli, 2-8 Settembre 2001, edited by Alois van Tongerloo and Luigi Cirillo, 373-84. Turnhout: Brepols.

Tardieu, Michel. 2008. Manichaeism. Urbana, Ill: University of Illinois Press.

Tawil, Dalia. 1979. "The Purim Panel in Dura in the Light of Parthian and Sasanian Art." Journal of Near Eastern Studies 38 (2): 93-109. https://doi.org/10.1086/372720.

Utas, Bo. 1985. "Mānistān and Xānaqāh." Edited by E. J. Brill. Papers in Honour of Professor Mary Boyce (Acta Iranica) 24,25 (II): 655-64.

Weitzmann, Kurt, and Herbert L. Kessler. 1990. The Frescoes of the Dura Synagogue and Christian Art. Dumbarton Oaks Studies 28. Washington, D.C: Dumbarton Oaks Research Library and Collection.

Wharton, Annabel Jane. 1995. Refiguring the Post Classical City: Dura Europos, Jerash, Jerusalem, and Ravenna. Cambridge: Cambridge University Press.

Williams, John. 1999. "The Beginnings of Biblical Illustration." In Imaging the Early Medieval Bible, edited by John Williams, 9-60. The Penn State Series in the History of the Book. University Park, Pa: Pennsylvania State Univ. Press. 